\title{
Implementation and evaluation of online gas-phase chemistry within a regional climate model (RegCM-CHEM4)
}

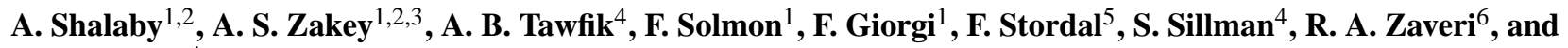 \\ A. L. Steiner ${ }^{4}$ \\ ${ }^{1}$ Earth System Physics Group, International Centre for Theoretical Physics, Trieste, Italy \\ ${ }^{2}$ Egyptian Meteorological Authority (EMA), Cairo, Egypt \\ ${ }^{3}$ Danish Meteorological Institute (DMI), Copenhagen, Denmark \\ ${ }^{4}$ Department of Atmospheric, Oceanic and Space Sciences, University of Michigan, Ann Arbor, Michigan, USA \\ ${ }^{5}$ Department of Geosciences, University of Oslo, Norway \\ ${ }^{6}$ Atmospheric Sciences and Global Change Division, Pacific Northwest National Laboratory, Richland, Washington, USA \\ Correspondence to: A. L. Steiner (alsteiner@umich.edu)
}

Received: 1 January 2012 - Published in Geosci. Model Dev. Discuss.: 17 January 2012

Revised: 13 April 2012 - Accepted: 26 April 2012 - Published: 22 May 2012

\begin{abstract}
The RegCM-CHEM4 is a new online climatechemistry model based on the International Centre for Theoretical Physics (ICTP) regional climate model (RegCM4). Tropospheric gas-phase chemistry is integrated into the climate model using the condensed version of the Carbon Bond Mechanism (CBM-Z; Zaveri and Peters, 1999) with a fast solver based on radical balances. We evaluate the model over continental Europe for two different time scales: (1) an event-based analysis of the ozone episode associated with the heat wave of August 2003 and (2) a climatological analysis of a six-year simulation (2000-2005). For the episode analysis, model simulations show good agreement with European Monitoring and Evaluation Programme (EMEP) observations of hourly ozone over different regions in Europe and capture ozone concentrations during and after the summer 2003 heat wave event. For long-term climate simulations, the model captures the seasonal cycle of ozone concentrations with some over prediction of ozone concentrations in non-heat wave summers. Overall, the ozone and ozone precursor evaluation shows the feasibility of using RegCMCHEM4 for decadal-length simulations of chemistry-climate interactions.
\end{abstract}

\section{Introduction}

The role of atmospheric chemistry in the climate system is now recognised as being of central importance (IPCC, 2007). Climate-chemistry interactions and the evolution of air quality over the coming decades depend on many factors, such as the growth of pollutant emissions due to worldwide economic development, localized emissions in high activity areas such as megacities, and changes in climatic factors such as temperature and precipitation. Many recent studies focusing on the impact of increased greenhouse gas concentrations on air quality have found an increase in tropospheric ozone as temperatures and greenhouse gas concentrations increase (e.g., Hogrefe et al., 2011; Andersson and Engard, 2010; Weaver et al., 2009; Zhang et al., 2008; Leibenspeger et al., 2008; Hedegaard et al., 2008; Meleux et al., 2007; Giorgi and Meleux, 2007; Forkel and Knoche, 2006; Stevenson et al., 2005; Langner et al., 2005). Specifically, ozone is an important component in the troposphere because (1) it is a leading indicator of poor air quality that adversely affects human health and natural ecosystems (e.g., WHO, 2003) and (2) has the ability to act as a greenhouse gas. However, simulations of tropospheric ozone can be complex because it is a relatively short-lived species with a lifetime of several days to weeks and exhibits a broad spatial heterogeneity (Jacob and Winner, 2009). 
A number of chemistry-climate models with various levels of offline and online coupling between the chemistry and atmospheric dynamics have been developed to investigate the interactions between climate and air quality (reviewed in Zhang, 2008). "Offline" coupling uses the meteorological output from weather or climate models to drive chemistry transport models, requiring two separate model simulations to study the effects of climate on air quality. Offline regional coupling has been more widely used and many studies have addressed the issue of the effects of climate change on regional ozone concentrations using the offline method (e.g., Langner et al., 2005; Szopa et al., 2006; Steiner et al., 2006; Meleux et al., 2007; Krüger et al., 2008; Liao et al., 2009; Chen et al., 2009). However, a preferred method to address issues of chemistry-climate interactions is to use fully coupled or "online" chemistry-climate models. Online methods directly transmit meteorological fields produced by the climate model to a chemistry module and calculate the concentration of climate-relevant tracers at a time step on the order of minutes. The radiative forcing of these tracers then feeds back into the climate model to affect temperatures and regional circulation. This technique is optimal yet computationally demanding, because ozone formation chemistry is complex and requires a large number of species to track in a three-dimensional framework. Most online coupled chemistry-climate models are global scale with coarse spatial resolutions (e.g., Emmons et al., 2010). Computational and physico/chemical complexity has, thus, prevented the widespread implementation of high-resolution, coupled chemistry-climate models for long-term climate integrations. To date, only a few regional climate models (RCMs) include online coupling with a range of chemical complexity (e.g., Jacobson et al., 1996; Jacobson, 1997a, b; Qian and Giorgi, 1999; Grell et al., 2005; Forkel and Knoche, 2006; Solmon et al., 2006; Zhang et al., 2010).

The intent of the RegCM-CHEM4 model development presented here is to accurately simulate ozone while allowing for decadal-scale climate simulations. To date, several offline methods have been developed using the CAMx atmospheric chemistry model with RegCM to simulate air quality (Katragkou et al., 2011; Zanis et al., 2011; Huszar et al., 2012). In this study, we discuss the full integration of gasphase chemistry into RegCM4 and provide a first assessment of the coupled model performance over a European regional domain. We assess the ability of the RegCM-CHEM4 to simulate ground-based ozone and its precursors for (1) a shortterm model evaluation for the heat wave of August 2003 and (2) an analysis of a six-year simulation to assess the suitability for long-term climate simulations. For the one-month case study, we select the summer of 2003 because it was one of the hottest on record in Europe (Schär et al., 2004). JuneJuly-August (JJA) average temperatures were more than $5^{\circ} \mathrm{K}$ warmer than the 1961-1990 average (Fink et al., 2004) and exceeded the next highest anomaly by a factor of two in some locations (Schär et al., 2004). During this time period, ozone concentrations and regional air pollution was extremely high due to the anomalous weather patterns (e.g., Vautard et al., 2005; Ordóñez et al., 2005; Hodzic et al., 2006; Struzewska and Kuminski, 2008; Solberg et al., 2008), contributing to health crises in several countries and triggering drought and a crop shortfall in Southern Europe. This region and time period has been one of great interest, and most models have found that biosphere-atmosphere feedbacks via dry deposition and isoprene emissions can play an important role in simulating regional ozone (Vautard et al., 2005; Solberg et al., 2008; Ordóñez et al., 2010). These feedbacks, high temperatures and ozone maxima make it an optimal test case to evaluate the simulations of coupled climate-chemistry interactions.

Section 2 provides a basic description of the relevant climate and chemistry components of RegCM-CHEM4. Section 3 describes the model simulation of the ozone episode associated with the 2003 heat wave over Europe and Sect. 4 includes an analysis of six-year simulations over the same domain to illustrate the suitability of the model for long-term simulations. We conclude in Sect. 5 by addressing the uncertainties in the coupled model, plans for future work and a guideline for use in future studies.

\section{Model description}

\subsection{Regional Climate Model version 4 (RegCM4)}

The climate component of the coupled model is the RegCM4, a model developed and maintained at the Abdus Salam International Centre for Theoretical Physics (ICTP) for over a decade (Pal et al., 2007; Giorgi et al., 2012). RegCM4 is a hydrostatic, sigma coordinate model described in Giorgi et al. (2012), which has been used for a wide range of applications across the globe (Giorgi and Mearns, 1999; Giorgi et al., 2006). There are several options for the parameterization of model physics and in the simulations presented here, we employ the mass-flux cumulus scheme of Grell (1993), the resolvable precipitation scheme of Pal et al. (2000), the non-local planetary boundary layer parameterization of Holtslag and Bouville (1993), and the radiation scheme of the CCM3 (Kiehl et al., 1996. Surface processes are treated using the Community Land Model version 3.5 (Oleson et al., 2008; Tawfik and Steiner, 2011). The reader is referred to Giorgi and Mearns (1999), Pal et al. (2007) and Giorgi et al. (2012) and references therein for a more detailed description of RegCM4. The simulations presented here use a dynamical model time step of $200 \mathrm{~s}$ with the land model called every $600 \mathrm{~s}$.

\subsection{Trace gas continuity equation}

Prior RegCM versions have implemented a chemical transport scheme to study the transport, fate and radiative impact of atmospheric aerosols (e.g., Qian and Giorgi, 1999; Solmon 
et al., 2006). In this study, we modify the RegCM4 chemical transport module to include gas-phase species using a mass continuity equation for each $\operatorname{tracer}(i) \chi^{i}$ (Solmon et al., 2006):

$$
\begin{aligned}
& \frac{\partial \chi^{i}}{\partial t}=-V \cdot \nabla \chi^{i}+F_{\mathrm{H}}^{i}+F_{\mathrm{V}}^{i}+T_{\mathrm{cum}}^{i} \\
& +S_{\mathrm{r}}^{i}-R_{\mathrm{w}, \mathrm{ls}}^{i}-R_{\mathrm{w}, \mathrm{cum}}^{i}-D_{\mathrm{dep}}^{i}+R_{\mathrm{net}}^{i}
\end{aligned}
$$

The first term in the right-hand side of Eq. (1) is the horizontal and vertical advection of the tracer concentration, $F_{\mathrm{H}}^{i}$ and $F_{\mathrm{V}}^{i}$ are horizontal and vertical turbulent diffusion, respectively, $T_{\text {cum }}^{i}$ is the vertical transport by cumulus clouds, $S_{\mathrm{r}}^{i}$ is the emission term, $R_{\mathrm{w}, \mathrm{ls}}^{i}, R_{\mathrm{w}, \text { cum }}^{i}$ are the wet removal terms by resolvable scale and cumulus precipitation, respectively, $D_{\text {dep }}^{i}$ is the dry deposition and $R_{\text {net }}^{i}$ is the net production by gas-phase reactions. Advection, diffusion and cumulus transport are parameterized as in Solmon et al. (2006). Dry and wet deposition parameterizations are discussed in Sect. 2.4. By solving this equation within the RegCM dynamical core, we can account for the online, coupled simulation of atmospheric chemistry and climate.

We solve the tendency equation (Eq. 1) sequentially in two steps. In the first step, all processes except $R_{\text {net }}^{i}$ are solved using the leapfrog scheme, while in the second step we solve the $R_{\text {net }}^{i}$ term. This method provides the ability to run the chemistry with a longer time step than that of the other processes. The chemistry mechanism is called every $1000 \mathrm{~s}$ or fifth model time step and calculates the chemistry tendency for each tracer species. This chemistry tendency is then applied to every time step when the chemistry module is not called to produce a smooth chemical tracer time evaluation. In the simulations presented here, aerosol transport is not included though has been tested and integrated with the gasphase chemistry in other simulations.

\subsection{Gas phase mechanism and solver}

Prior work tested several atmospheric chemistry mechanisms in the model (results not shown) and in this study, we select the photochemical mechanism CBM-Z (Carbon Bond Mechanism; Zaveri and Peters, 1999) because it affords a reasonable trade-off between accuracy and computational efficiency. CBM-Z is based on the widely used CBM-IV scheme (Gery et al., 1989) developed for use in urban air-shed models for air quality applications. While both CBM-IV and CBM-Z use lumped species that represent broad categories of volatile organic compounds (VOC) based on carbon bond structure, CBM-Z also includes species and reactions that are important at regional to global scales and longer time periods than typical urban airshed simulations. Specifically, these updates include (1) explicit treatment of lesser reactive alkanes such as methane and ethane, (2) revised parameterizations of higher alkanes, (3) use of two lumped structure species for olefins (internally and terminally bonded carbon atoms $\mathrm{C}=\mathrm{C}$ ) with different reactivities, (4) alkyl peroxy radical $\left(\mathrm{RO}_{2}\right)$ self reactions, which has been shown to become important in $\mathrm{NO}_{\mathrm{x}}$-limited, remote environments, (5) reactions of alkyl and acyl peroxy radicals with the $\mathrm{NO}_{3}$ radical, which becomes important at night, (6) treatment of longer-lived organic nitrates and hydroperoxides, and (7) the addition of more detailed isoprene chemistry and a distinct isoprene peroxy radical. Overall, these mechanism changes improve the simulation of long-lived VOCs and also can better account for the chemistry transitions from urban to rural areas. CBM-Z has been extensively used in atmospheric chemistry simulations and has been implemented in the coupled WRF-Chem regional meteorology-chemistry model (Luo and Yu, 2011; Yang et al., 2011, Chapman et al., 2009), and the Nested Air Quality Prediction Modeling System (NAQPMS) (Wu et al., 2011; Li et al., 2008). The CBM-Z mechanism has been used to interpret field measurements collected at urban (Zaveri et al., 2003; Jiang and Fast, 2004; Fast et al., 2006; Zaveri et al., 2010a, b) and regional (Fast et al., 2002; Fast and Heilman, 2005) scales. This selection represents a computationally efficient mechanism that can reliably simulate chemistry over a range of spatial and temporal scales.

Calculating the time evolution of gas-phase chemistry requires numerically integrating a set of stiff ordinary differential equations and is among the most computationally expensive operations performed in a photochemical grid model. A suite of numerical procedures with efficient solutions has been developed (e.g., Jacobson et al., 1996), and here we apply the computationally rapid radical balance method (RBM) of Sillman et al. (1991) and Barth et al. (2002) to solve the tendency equation for photochemical production and loss. RBM utilizes the fact that much of the complexity of tropospheric chemistry stems from the HOx radical family $\left(\mathrm{OH}, \mathrm{HO}_{2}\right.$ and $\left.\mathrm{RO}_{2}\right)$, which has a limited set of of sources and sinks. The method solves reverse-Euler equations for $\mathrm{OH}$ and $\mathrm{HO}_{2}$ based on the balance between sources, sinks and (if applicable) prior concentrations at the start of the time step. Reverse Euler equations for other species are solved in a reactant-to-product order, in some cases involving pairs of rapidly interacting species, and with some modifications to increase accuracy in exponential decay situations. The procedure is equivalent to a reverse Euler solution using sparse-matrix techniques, but with the matrix inversion linked specifically to the behaviour of $\mathrm{OH}$ and other species in the troposphere.

\subsection{Photolysis rates}

Photolysis rates are determined as a function of several meteorological and chemical inputs including altitude, solar zenith angle, overhead column densities for $\mathrm{O}_{3}, \mathrm{SO}_{2}$ and $\mathrm{NO}_{2}$, surface albedo, aerosol optical depth, aerosol single scattering albedo, cloud optical depth and cloud altitude. These variables (excluding $\mathrm{SO}_{2}$ and $\mathrm{NO}_{2}$ column densities) are provided in the online coupled code by other RegCM modules including the radiative transfer, 
land surface and cloud parameterization schemes. Quantities are updated every 3-30 min depending on the source code module. $\mathrm{SO}_{2}$ and $\mathrm{NO}_{2}$ column densities are constant in the model and derived from vertical profiles as described in the United States Standard Atmosphere (NASA, 2000). Rates for specific conditions are interpolated from an array of pre-determined values based on the Tropospheric Ultraviolet-Visible Model (TUV) developed by Madronich and Flocke (1999) and a pseudo-spherical discrete ordinates method (Stamnes et al., 1988) with 8 streams. The 8-stream TUV is an accurate method for determining photolysis rates, but is computationally too expensive for online application in 3-D models, therefore, we use tabulated and interpolated values in our simulations.

Photolysis rates can be significantly affected by the presence of clouds. The method used to correct for cloud cover is based on Chang et al. (1987), which requires information on cloud optical depth for each model grid cell. Optical depth is used to reduce photolysis rates for layers within or below clouds to account for UV attenuation or to increase photolysis rates due to above-cloud scattering. The correction of clear-sky values depends on whether the location is below, above, or within the cloud. Cloud optical depths and cloud altitudes from RegCM-CHEM are used in the photolysis calculations, thereby directly coupling the photolysis rates and chemical reactions to meteorological conditions at each model time step. The adjustment to clear sky photolysis rate for below and within the cloud layer is:

$$
J_{\text {cloud }}=J_{\text {clear }}\left[1+F_{\mathrm{c}}\left(1.6 \tau_{\mathrm{r}} \cos \theta-1\right)\right]
$$

where $F_{\mathrm{c}}$ is cloud cover fraction, $\theta$ is the zenith angle and $\tau_{\mathrm{r}}$ is the cloud transmissivity (calculated as a function of the cloud optical depth). In general, below cloud photolysis rates will be lower than the clear sky value due to the reduced transmission of radiation through the cloud. Similarly, photolysis rates are enhanced above the cloud due to the reflected radiation from the cloud as follows:

$J_{\text {above }}=J_{\text {clear }}\left[1+F_{\mathrm{c}}\left(\left(1-\tau_{\mathrm{r}}\right) \cos \theta\right)\right]$

\subsection{Deposition}

Dry deposition is the primary removal process for trace gas species in the model, and is parameterized as three resistances in series: (1) aerodynamic resistance, (2) quasilaminar sub-layer resistance, and (3) bulk surface resistance that accounts for stomatal and non-stomatal uptake in plants and soil. Dry deposition is modelled for 29 gas phase species following the CLM4 dry deposition model (based on the Wesley (1989) dry deposition scheme), where the CLM land cover types are converted into the 11 Wesley land cover types. In the dry deposition scheme, we consider both stomatal and non-stomatal resistances, which is necessary as the stomatal uptake occurs only during the daytime for most chemical species. This leads to a more accurate representation of diurnal variations of dry deposition, a process crucial for climate-chemistry interactions. All resistances are calculated in the CLM land surface model, resulting in consistent modelled values with the simulated land-atmosphere meteorology.

Wet deposition is parameterized as in the MOZART global model (Horowitz et al., 2003; Emmons et al., 2010). In our simulations, we include the removal of $26 \mathrm{CBM}-\mathrm{Z}$ gas phase species based on the amount of large-scale precipitation as generated by the RegCM precipitation parameterization. Current simulations do not include wet removal by cumulus precipitation, but this inclusion is planned for future model versions. Because the August 2003 event was exceptionally dry, we do not expect that this will significantly impact our wet removal rates during the event analysis.

\subsection{Emissions inventories}

Emissions inventories implemented in RegCM-CHEM4 include anthropogenic emissions, emissions from biomass burning, and natural emissions from the biosphere (or biogenic emissions) (Fig. 1). These inventories vary greatly in terms of spatial (typically $1^{\circ} \times 1^{\circ}$ or $0.5^{\circ} \times 0.5^{\circ}$ in the horizontal) and temporal resolution (ranging from annual to monthly to hourly). The RegCM framework is designed for implementation over any regional-scale domain in the world, therefore, we develop an emissions pre-processor dataset that optimises the spatial and temporal scales of the available coarse inventories and are be adaptable to any location. We note that the use of these inventories results in relatively coarser grids than used in many regional air quality models, which are often developed for specific source regions by local, state and federal agencies. The preprocessor code regrids and interpolates the emissions data to the same model projection and resolution as needed by RegCM-CHEM4 and unifies the emission units for different inventories. The simulations presented in this manuscript include the MACCity emissions, which is an extension of the ACCMIP emissions dataset for 1990-2010 (Lamarque et al., 2010). This $0.5^{\circ} \times 0.5^{\circ}$ inventory represents annual changes in anthropogenic emissions and monthly inventories for biomass burning over the simulation years (2000-2005). Biogenic emissions are calculated in an online biogenic VOC model (the Model of Emissions of Aerosols and Gases from Nature (MEGAN); Guenther et al., 2006) implemented in RegCM with CLM (Tawfik et al., 2012). The online biogenic emissions use modelled temperature, radiation and soil moisture allowing for a consistent inventory based on modelled meteorology and climatology.

Monthly anthropogenic emissions inventories are employed in the model and we note that daily and diurnal variations are not prescribed in the anthropogenic emissions inventories, which may impact the daily minima and maxima ozone concentrations. Centres of high anthropogenic industrial emissions (indicated with $\mathrm{NO}_{\mathrm{x}}$ and alkane emissions) are concentrated near urban areas in Germany, 

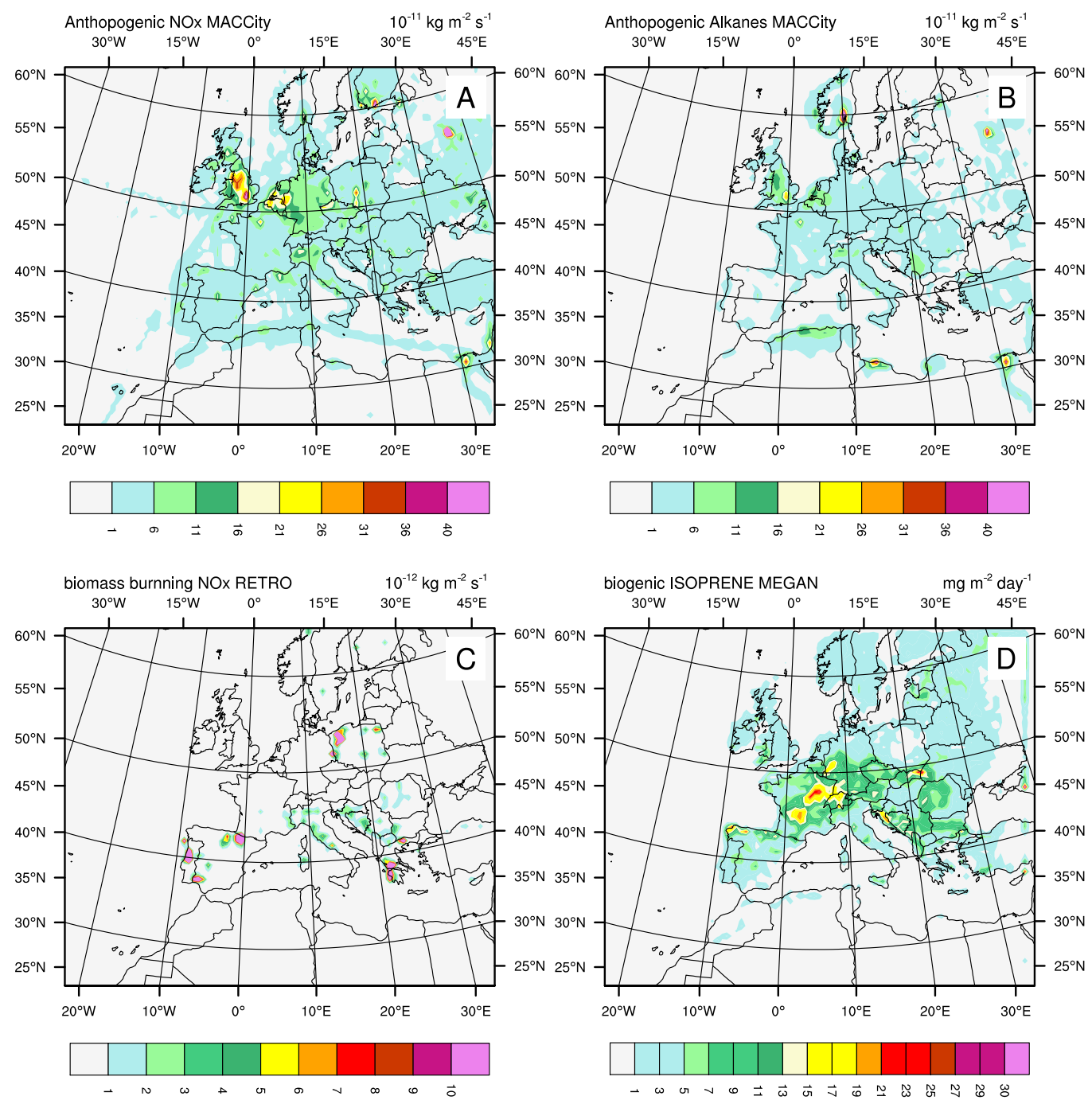

Fig. 1. Model domain and selected August 2003 emissions used in RegCM-CHEM, (a) $\mathrm{NO}_{\mathrm{x}}$ MACCity anthropogenic emissions $\left(10^{-11} \mathrm{~kg} \mathrm{~m}^{-2} \mathrm{~s}^{-1}\right)$, (b) anthropogenic MACCity alkane emissions $\left(10^{-11} \mathrm{~kg} \mathrm{~m}^{-2} \mathrm{~s}^{-1}\right)$, (c) $\mathrm{NO}_{\mathrm{x}}$ biomass burning emissions from the RETRO inventory $\left(10^{-11} \mathrm{~kg} \mathrm{~m}^{-2} \mathrm{~s}^{-1}\right)$, and (d) biogenic isoprene emissions calculated online with the MEGAN model (mg m ${ }^{-2}$ day $^{-1}$ ).

France and the United Kingdom (Fig. 1a, b). Biomass burning emissions are most pronounced in Portugal, northern Poland and in many of the Italian and Greek Mediterranean areas during August 2003 (Fig. 1c). August biogenic emissions are localized near forested areas, with the largest emissions in central Europe in France, Germany and northern Spain (Fig. 1d). For the climatological simulations, the biomass burning emissions and biogenic VOC emissions exhibit a strong seasonal cycle with higher emissions in the summer and lower emissions in the winter. Biogenic emissions approach zero during the winter with summer emission rates nearly two orders of magnitude higher than winter, consistent with other emissions studies in Europe (Poupkou et al., 2010; Steinbrecher et al., 2009).

\subsection{Simulation design}

To test the ability of the coupled RegCM-CHEM4 to simulate ozone, we conduct one simulation for $6.5 \mathrm{yr}$ from 1 June 1999 - 31 December 2005. The first six months of the simulation is for climate model spin up and is not included in the analysis time period of 2000-2005. The heatwave event analysis evaluates hourly output from the month of August 2003 (Sect. 3) and the climatological ozone analysis evaluates the simulation of ozone for the full six-year time period (1 January 2000 - 31 December 2005; Sect. 4). The model domain (Fig. 1) has a horizontal resolution of $60 \mathrm{~km} \times 60 \mathrm{~km}$ and 18 vertical levels. Because RegCM4 is a limited-area model, meteorological lateral boundary forcings are required. For present-day simulations such as the one here, initial and lateral boundary conditions for the 


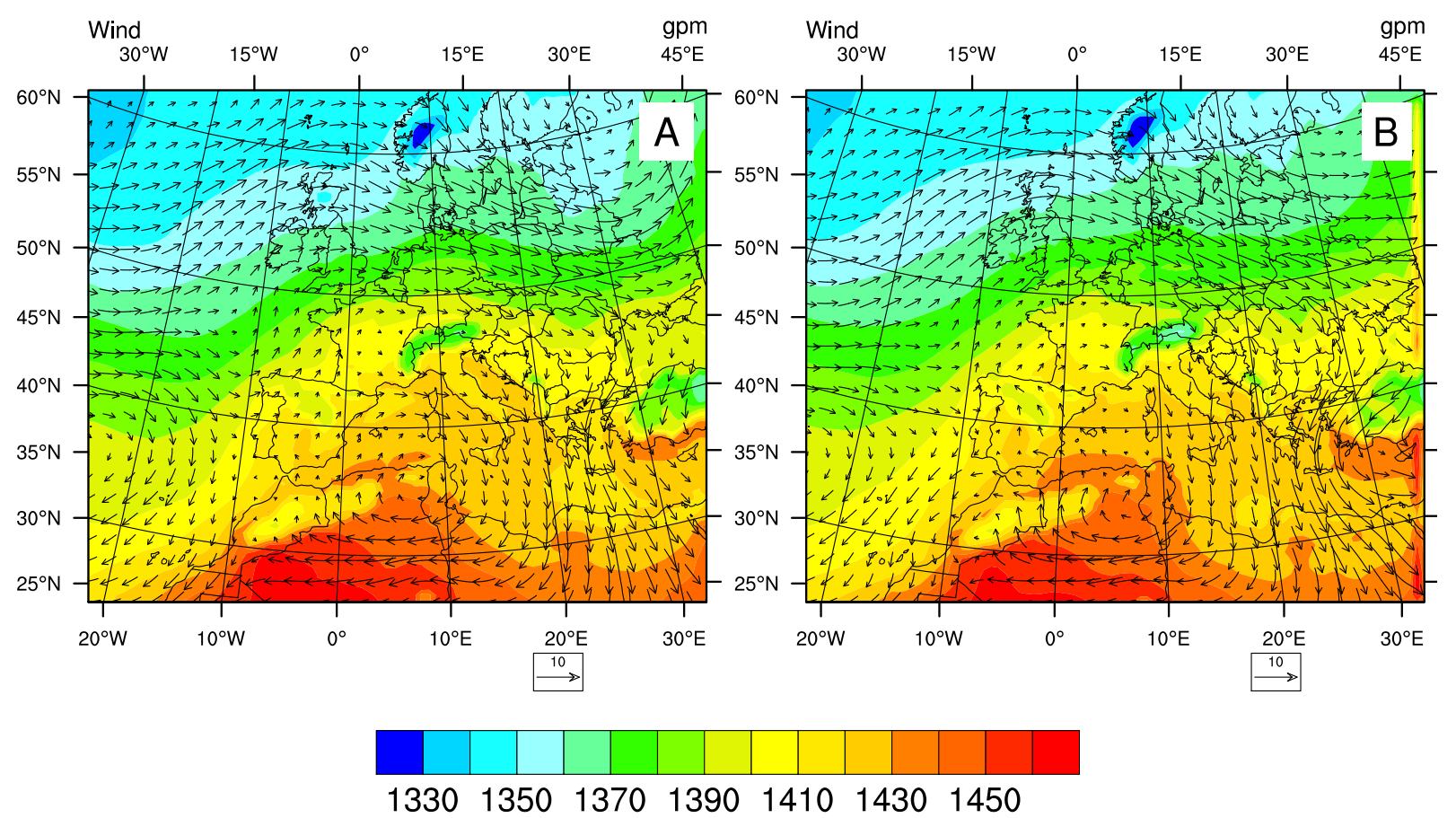

Fig. 2. (a) ERA-Interim Reanalysis of $850 \mathrm{mb}$ geopotential surface $(\mathrm{m})$ and wind field $\left(\mathrm{m}^{\mathrm{s}}-1\right)$ averaged over August 2003. (b) RegCMCHEM $850 \mathrm{mb}$ geopotential surface and wind field averaged over August 2003.

meteorological fields are provided by ERA-Interim analysis every six hours with weekly ERA sea surface temperatures (Dee et al., 2011). Climatological chemical boundary conditions are provided by the global, three-dimensional MOZART chemical transport model by using a monthly average of years 2000-2007 (Horowitz et al., 2003; Emmons et al., 2010). The model top ( $50 \mathrm{hPa}$, corresponding to the lower stratosphere) uses a climatological ozone concentration based on interpolated MOZART ozone fields. Therefore, the model top layer contains ozone concentrations comparable to the stratosphere, yet ozone is not transported across this boundary and the model cannot capture large dynamical changes that deviate from the 2000-2007 climatological seasonal cycle such as exceptional stratospheric ozone intrusions. The use of a climatological average results in the lack of interannual variability in our lateral and vertical chemical boundary conditions, which can have important implications for interannual ozone variability (see Sect. 5). However, we implement the climatological values for computational efficiency during model development and test simulations. This model setup allows the evaluation of modelled versus observed ozone concentrations on a realistic basis for short-term event simulations in a regional weather-air quality framework (Sect. 3) and also for longer integrations as a regional climate-air quality model (Sect. 4). To provide computational context, the 6.5-yr simulation for this domain using 45 processors required $47 \mathrm{~h}$ and $20 \mathrm{~min}$ of computation time.

\section{European ozone event}

\subsection{Meteorological conditions}

Maximum temperatures of $308-313 \mathrm{~K}$ were repeatedly recorded in July and the first half of August across Europe in 2003. As noted in several other studies (e.g., Beniston and Diaz, 2004; Black et al., 2004), these extreme weather conditions were caused by an anti-cyclone positioned over Western Europe, blocking the rain-bearing depressions originating over the Atlantic Ocean from reaching the continent. This exceptional length of these stagnant conditions (over 20 days) increased the flow of very hot, dry air from sub tropical regions to Europe. The extreme event and the anomalously warm and dry conditions increased ozone concentrations over Europe to unusually high values (Vautard et al., 2005; Meleux et al., 2007; Solberg et al., 2008).

The ERA-Interim reanalysis data (interpolated to model grid; Fig. 2a) displays this pattern and the RegCM-CHEM4 accurately simulates this high pressure and anti-cyclonic circulation over Europe (Fig. 2b). RegCM-CHEM4 places the center of the anti-cyclonic feature in approximately the same location as the driving reanalysis, yet simulates slightly stronger winds over central and northern Europe. Outflow from central Europe to the Mediterranean is slightly stronger in the RegCM than the reanalysis. Because the RegCMCHEM is driven by ERA-Interim boundary conditions (updated every six hours), this agreement is not surprising, but 

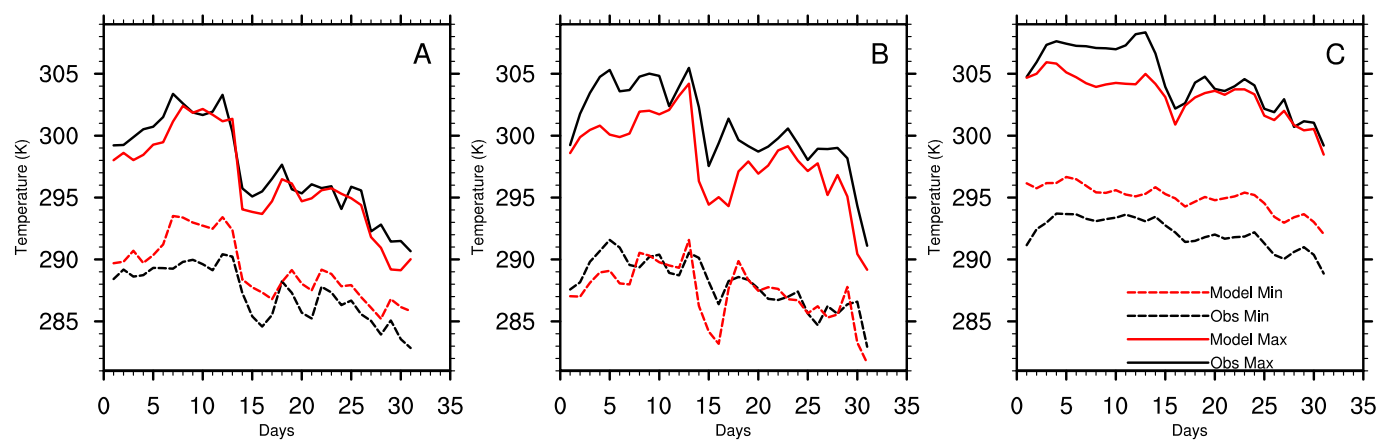

Fig. 3. August 2003 observed (black) and modelled (red) maximum (solid line) and minimum (dashed line) surface air temperature (degrees K) for (a) ECAD stations in Northern Europe (latitudes greater than $50^{\circ} \mathrm{N}$ ), (b) ECAD stations in Central Europe (latitudes $47-50^{\circ} \mathrm{N}$ ), and (c) ECAD stations in Southern Europe (latitudes less than $47^{\circ} \mathrm{N}$ ).

we note this pattern to show that the interior model domain replicates the main meteorological features leading to the high ozone event. This circulation pattern is also conducive to subsidence conditions that favour ozone accumulation over the continent (Vautard et al., 2005).

During August 2003, RegCM-CHEM4 simulates surface air temperatures of $290-296 \mathrm{~K}$ over continental Europe, with temperatures increasing up to $303 \mathrm{~K}$ in the Iberian Peninsula and Italy. We compare daily maximum temperature $\left(T_{\max }\right)$ and daily minimum temperature $\left(T_{\min }\right)$ data from the European Climate Assessment and Dataset (ECAD) observation stations (http://eca.knmi.nl/dailydata/index.php) with the matching model grid cell from RegCM-CHEM4 over the August 2003 event (Fig. 3) for stations located in Northern Europe (defined as all ECAD sites north of $50^{\circ} \mathrm{N}$ ), Central Europe (ECAD sites within the latitude range of $47-50^{\circ} \mathrm{N}$ ), and Southern Europe (ECAD stations south of $47^{\circ} \mathrm{N}$ ). In the northern Europe regions, the model reproduces $T_{\max }$ with a slight under prediction of $1-2 \mathrm{~K}$ during the heat wave and very little bias in the second half of August. However, $T_{\min }$ is over predicted by the model by up to $5 \mathrm{~K}$ during the heat wave, with a reduced bias of 1-3 K after the passage of the system. In central Europe, the model underestimates $T_{\max }$ (up to $6 \mathrm{~K}$ during the heat wave), but shows very little bias in $T_{\min }$. In southern Europe, the model underestimates $T_{\max }$ during the heatwave by about $3 \mathrm{~K}$ yet shows good agreement in the second half of the month. $T_{\min }$ is consistently over predicted by about $3 \mathrm{~K}$ throughout the full month in southern Europe. The effect of these temperature biases on ozone is discussed in Sect. 3.3.

\subsection{Ozone episode development}

To understand the evolution of the ozone episode across Europe, we compare first layer (approximately $50-100 \mathrm{~m}$ height) simulated ozone concentrations at 14:00 UTC for six selected days $(1,4,8,10,12,16$ August) with ozone surface observations from the European Monitoring and Evaluation Programme (EMEP) station network (http://www.emep.int;
Fig. 4). These six days represent the onset of the August 2003 ozone episode and its behaviour until the end of the episode (approximately 15 August). The production of ozone is affected by meteorology as described in Sect. 3.1, yet is very sensitive to the location and magnitude of emissions and the resulting $\mathrm{VOC} / \mathrm{NO}_{\mathrm{x}}$ ratio. In the first two days of August, maritime westerly flow over western Europe leads to low to moderate ozone concentrations (50-80 ppb) in northern and central Europe (Fig. 4a), with slightly higher concentrations in eastern France and Germany. The model represents these spatial features well, with biases less than $5 \mathrm{ppb}$ throughout most of central Europe, although there are a few stations in central Spain and western Germany where the model under predicts the observations by $10-15 \mathrm{ppb}$.

On 3-4 August, ozone builds up in the boundary layer with concentrations exceeding the European standards (90 ppb) south and south west of the Ruhr region and over central France (Fig. 4b). Model biases in this region are less than $5 \mathrm{ppb}$. The anticyclonic circulation causes the high ozone region to shift clockwise on 4 August from southern Germany to western France on 8-10 August (Fig. 4c, d). On $12 \mathrm{Au}-$ gust, very high ozone levels (100-120 ppb) occur over most of France and Western Europe (Fig. 4e). From 8 August (Fig. 4c) to 12 August (Fig. 4e), the model produces high concentrations in Central Germany but measurements at this hotspot are lacking and surrounding observations are greater than modelled concentrations by about $16 \%$. Other elevated observations in Switzerland are under predicted by the model by about $10 \mathrm{ppb}$. These elevated modelled concentrations begin to dissipate on 15 August as the air mass moves towards Eastern Europe (Fig. 4f), and the limited observations suggest that concentrations shift slightly back to the east over Switzerland. The model reproduces this general pattern yet still slightly underestimates ozone concentrations by $4 \%$. Similar ozone concentration magnitudes and positioning were noted by Vautard et al. (2005). Despite these model biases during the event, the model reproduces the circulation of ozone fairly well. 


\section{Ozone Episode August 2003}
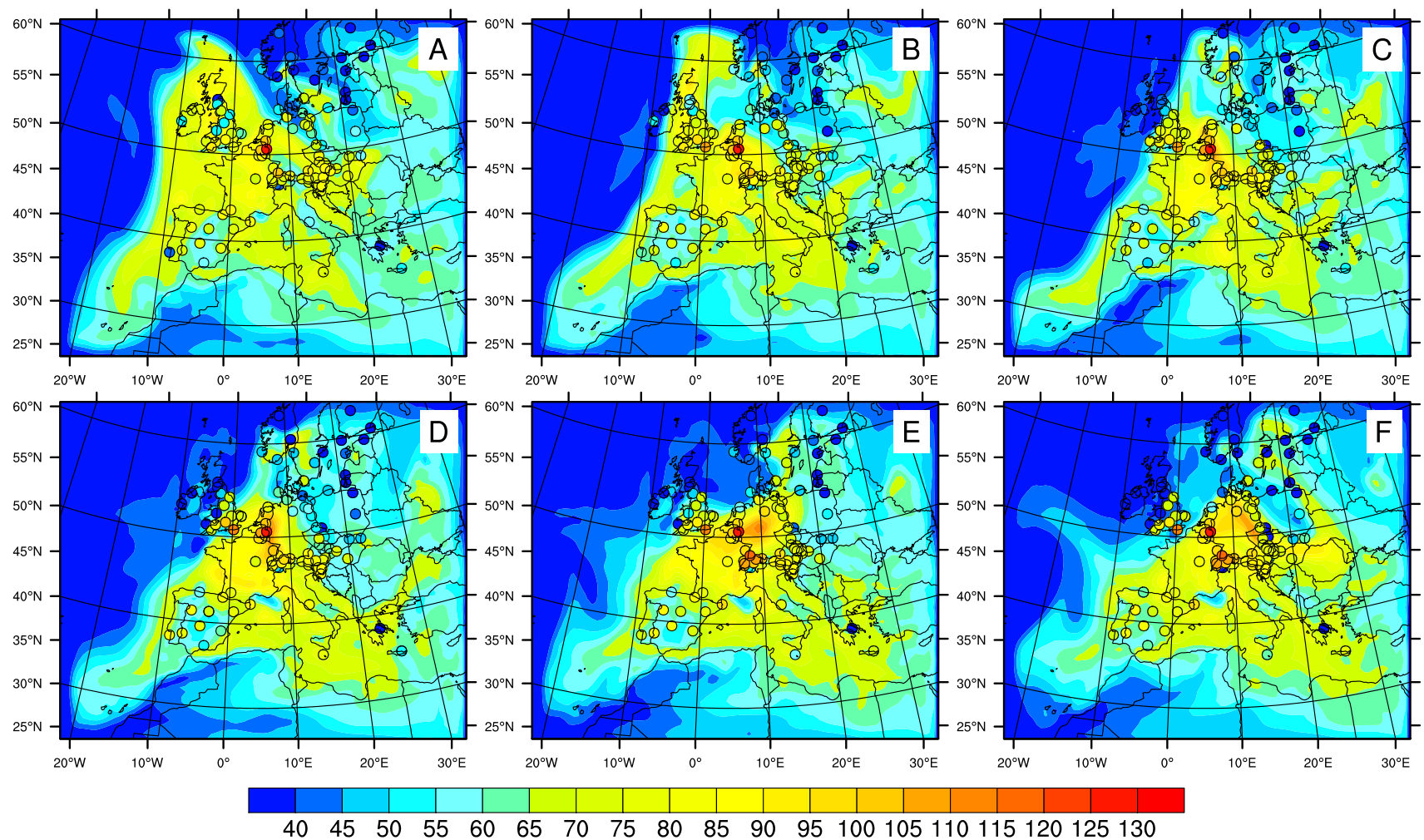

Fig. 4. Evolution of the ozone concentration field through the first two weeks of August 2003 corresponding to the core of the August 2003 heat wave. Each panel displays a concentration field in ppb at 14 h UT on (a) 1 August, (b) 4 August, (c) 8 August, (d) 10-August, (e) 12 August, (f) 16 August. EMEP station locations are shown in circles with observed ozone concentrations (colour of circle following contour legend).

\subsection{Ozone time series analysis}

To further examine the simulation of the 2003 August event ozone, we compare hourly observed surface ozone concentrations from EMEP stations with modelled ozone concentrations (Fig. 5) for four regions: (1) a selection of eight representative European stations noted by Solberg et al. (2008) including: Donon (FR08), Revin (FR09), Morvan (FR10), Peyrusse-Vieille (FR13), Campisabalos (ES09), Kosetice (ZC03), Waldhof (DE02), and Ueckermünde (DE26; this station replaces the Zingst site due to lack of data availability), (2) stations located in Northern Europe (defined as all EMEP sites north of $50^{\circ} \mathrm{N}$ ), (3) stations in Central Europe (EMEP sites within the latitude range of $47-50^{\circ} \mathrm{N}$ ), and (4) stations in Southern Europe (EMEP stations south of $\left.47^{\circ} \mathrm{N}\right)$.

When averaged over the eight representative stations, the model captures the observed diurnal evolution of the ozone episode (Fig. 5a). Daily minima and maxima are well reproduced by the model with biases less than $5 \mathrm{ppb}$. Most notably, RegCM-CHEM captures the sharp decrease in daily ozone maxima from 70-80 ppb during the early August event to $50-60 \mathrm{ppb}$ at the end of the event on 14 August. After this date, modelled concentrations are greater than observed with a daily maximum bias of 5-10 ppb. In the Northern Europe region (sites north of $50^{\circ} \mathrm{N}$ ), measured-modelled agreement is also strong with daily maxima typically within $5 \mathrm{ppb}$ of observed concentrations. During the ozone event in the Northern region, the model predicts ozone minima up to $12 \mathrm{ppb}$ greater than observed and is likely due to the higher than observed $T_{\min }$ in this region (Fig. 3a). This bias is reduced after the passage of the frontal system on $15 \mathrm{Au}$ gust in concert with an improvement in measured-modelled temperature agreement. In the Central European region (47$50^{\circ} \mathrm{N}$ ), the model captures the diurnal variations over the month of August, yet frequently underestimates the ozone maxima during the main part of the event (Fig. 4c) and we note that this time period is also one where the $T_{\max }$ bias is over $5 \mathrm{~K}$ (Fig. 3b). After the heat wave breaks on $14 \mathrm{Au}-$ gust, ozone concentrations are sometimes greater than observed and sometimes less; no clear bias is evident and these variations are not correlated with temperature biases. In the Southern region, the model underestimates the ozone maxima in the latter half of the heat wave event (6-12 August) in 

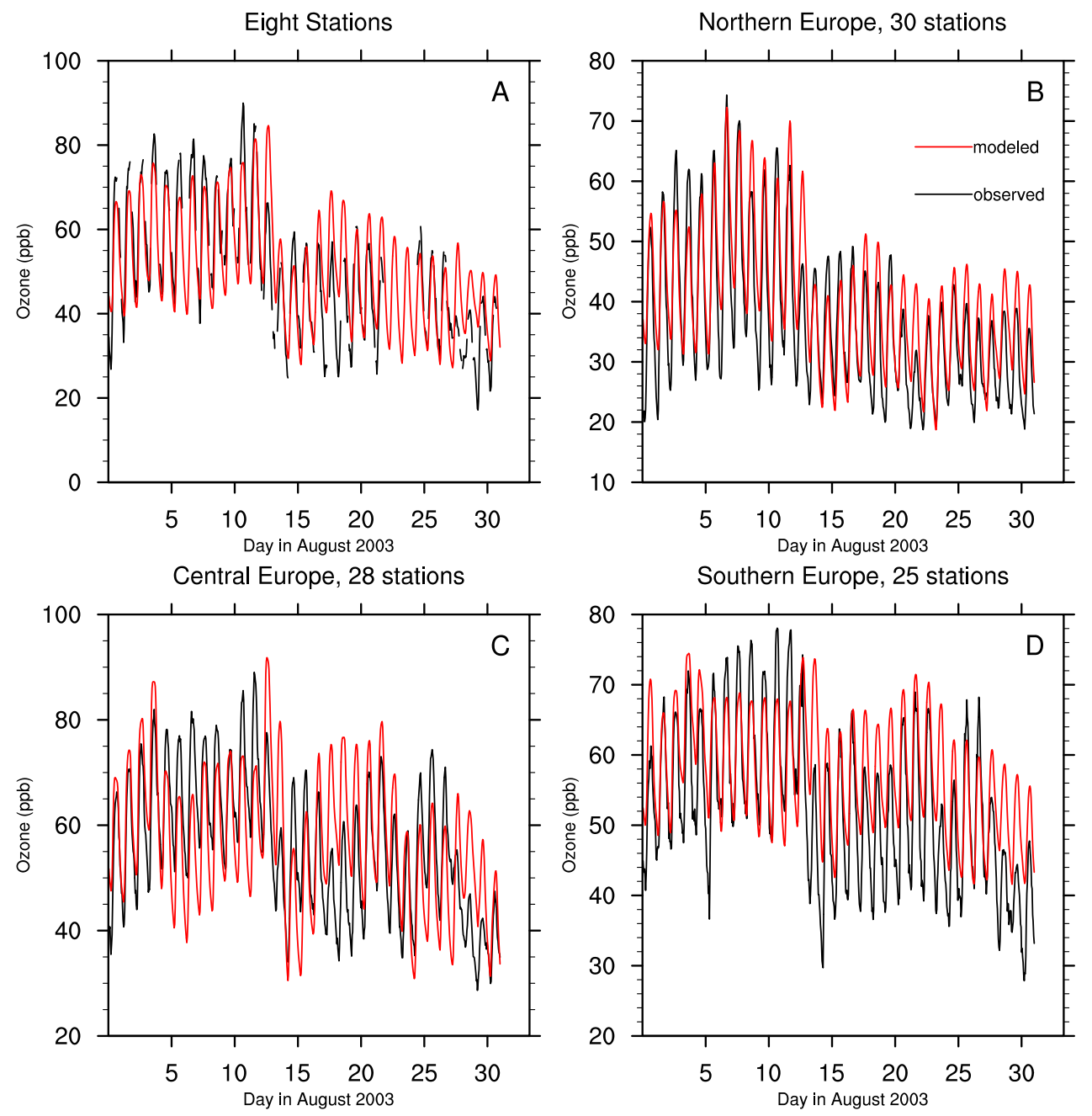

Fig. 5. Observed (black) and modelled (red) surface ozone concentrations (ppb) for (a) eight representative EMEP stations (see text for locations), (b) 30 EMEP stations in Northern Europe (latitudes greater than $50^{\circ} \mathrm{N}$ ), (c) 28 EMEP stations in Central Europe (latitudes $47-50^{\circ} \mathrm{N}$ ), and (d) 25 stations in Southern Europe (latitudes less than $47^{\circ} \mathrm{N}$ ).

conjunction with substantial cool biases in $T_{\max }$, yet overestimates $T_{\max }$ in the second half of the month. After the heat wave, modelled ozone minima are also higher than observed, showing a shifted diurnal cycle in the model to higher concentrations. In the southern region, $T_{\min }$ is consistently over predicted and is likely causing the accumulation of ozone even after the conclusion of the event.

Our results are comparable to other regional and global modelling studies of this event. For example, Vautard et al. (2005) used a high-resolution model (CHIMERE) comparable in resolution to RegCM-CHEM4 and found that the model can typically reproduce the diurnal cycle with underestimates of the ozone maxima during the event in the northern part of the domain and overestimates of the maxima in the southern part of the domain. Ordóñez et al. (2010) compared three global chemical transport models (MOZART, MOCAGE and TM5) and found that the models can typi- cally simulate the synoptic conditions that cause the event transition at mid-month, but the ozone bias exhibits a strong spatial variability as noted in our results. Other multi-model evaluations of summer ozone in Europe note that many models can easily simulate the diurnal cycle and generally tend to overestimate the ozone maxima except in cases of unusually high ozone such as the 2003 event (e.g., Delle Monache and Stull, 2003; van Loon et al., 2006; Vautard et al., 2009). Vautard et al. (2009) note an ensemble average overestimate of ozone in northern Europe and an underestimate in southern Europe. While the northern results are consistent with our simulations, the RegCM-CHEM4 over prediction in the southern region may be related to the land surface scheme and temperature feedbacks in this region.

To evaluate potential sources of $\mathrm{O}_{3}$ model bias in addition to those driven by temperature, we examine the diurnal cycles of modelled rates of net chemical production (ozone 

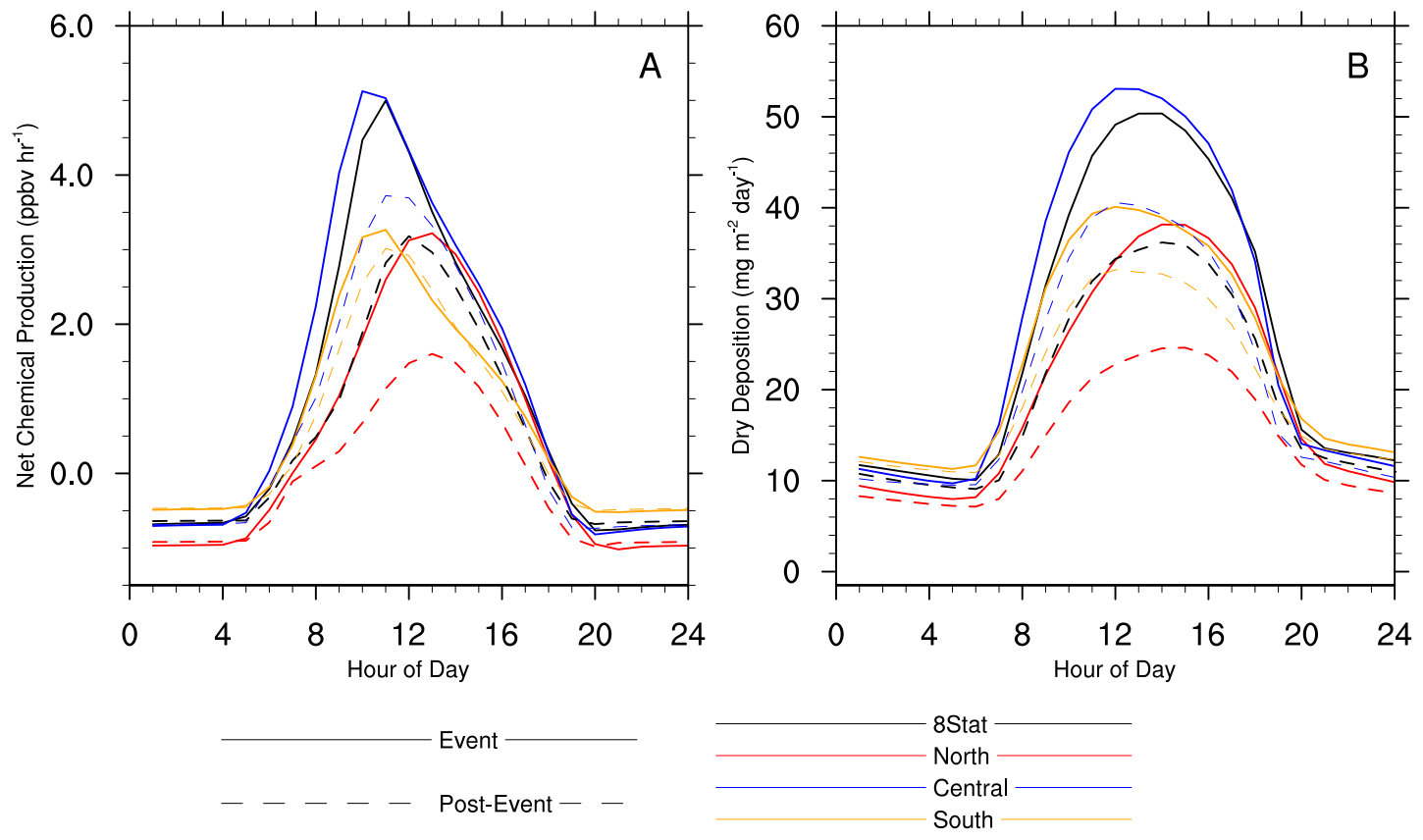

Fig. 6. Average diurnal cycle of rates during the ozone event (1-14 August 2003; solid lines) and after the ozone event (16-31 August 2003; dashed lines) for (a) modelled rates of net chemical production (ozone production-ozone loss; ppb $h^{-1}$ ) and (b) dry deposition rates (mg $\mathrm{m}^{-2} \mathrm{day}^{-1}$ ) for the four regions of analysis (as in Fig. 5; Sect. 3.3). Wet deposition rates were zero over this month

production - loss; $\mathrm{ppb} \mathrm{h}^{-1}$ ) for each region during and after the ozone event (Fig. 5d). During the event (1-14 August 2003), chemical production is highest (up to $5 \mathrm{ppbh}^{-1}$ ) in the Central region and over the 8-station average. Comparatively, net production rates during the daytime are smaller for the Northern and Southern regions $\left(\sim 3 \mathrm{ppbh}^{-1}\right)$; yet nighttime loss rates are much higher in the Northern region likely due to the titration of $\mathrm{O}_{3}$ by high $\mathrm{NO}_{\mathrm{x}}$ emissions in this region. This increase in nighttime chemical loss may be biased by the lack of diurnal cycle in $\mathrm{NO}_{\mathrm{x}}$ emissions, however, we note that we still observe an overestimation of the nighttime minima in the Northern region suggesting that it is not causing large problems in our model bias. Dry deposition rates for $\mathrm{O}_{3}$ are greater in the Central region and the 8 -station average and are driven by high atmospheric concentrations in these regions, with deposition decreasing in the Northern and Southern region where ozone surface concentrations are lower. After the event (16-31 August), daytime chemical production rates drop by about $40-60 \%$ in the Central and 8-station regions and are halved in the Northern region, with little change in nighttime net chemical loss of $\mathrm{O}_{3}$. This explains the event-based changes in Fig. 5, with higher ozone concentrations during the event and decreasing after the event. The Southern region does not show as strong a shift in $\mathrm{O}_{3}$ concentrations after the event as other regions (Fig. 5), reflected in small changes in the net production rate during and post-event $(\sim 10 \%)$ and could be attributed to the increased role of biogenic VOC in this region. Dry deposi- tion rates decrease by about $25-40 \%$ after the event in the Central and 8-station region, with greater decreases in the North $(60 \%)$ and less decreases in the South $(30 \%)$. Overall, both changes in chemistry and deposition contribute to the decrease in ozone concentrations after the event.

We note that there are several physical and emissions processes that could be contributing to these modelled-observed discrepancies. First, there is an overall warm bias in RegCMCHEM4 in the southern Mediterranean, which could amplify the online isoprene emissions and ozone formation and lead to higher modelled concentrations than observed. For example, in the Central and Southern regions, the model tends to simulate more ozone than observed in the second half of August 2003. Other studies have noted the role of drought stress during this time period, where the heat and drought stress over Europe have been postulated to increase stomatal closure, reduce dry deposition and increase ambient ozone concentrations (Solberg et al., 2008). Our simulations are slightly warmer than observed and because of the coupled land-atmosphere nature of the RegCM model, they likely capture this drought-deposition feedback and are not likely the cause of our ozone biases.

\subsection{Ozone precursors}

An evaluation of ozone precursors including $\mathrm{NO}_{2}$ concentrations and two select VOC species can provide further insight into model behaviour. We note the reduced sampling 

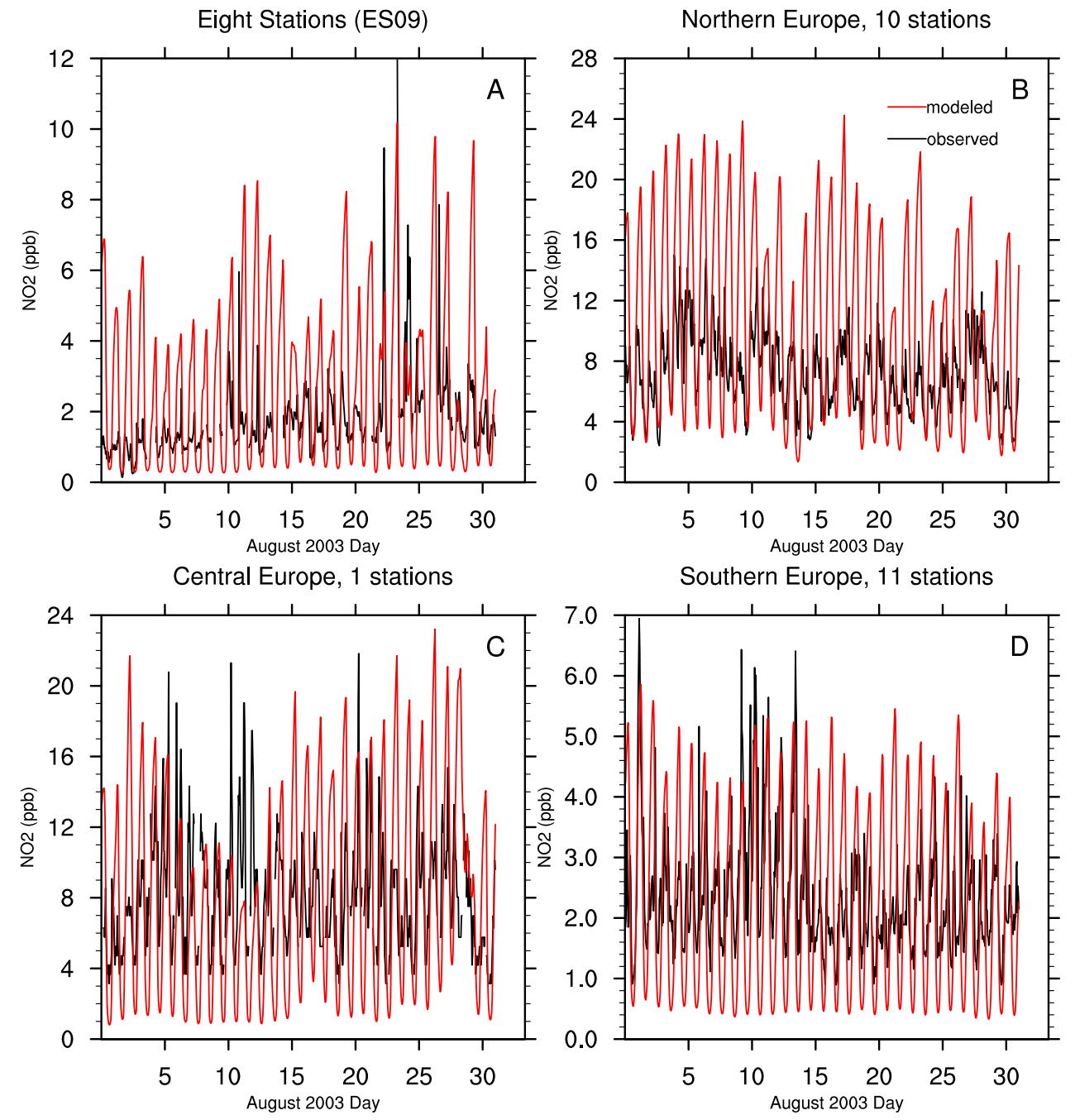

Fig. 7. Observed (black) and modelled (red) surface $\mathrm{NO}_{2}$ concentrations (ppb) for (a) one of the eight representative EMEP stations (ES09), (b) 10 EMEP stations in Northern Europe (latitudes greater than $50^{\circ} \mathrm{N}$ ), (c) 1 EMEP station in Central Europe (latitudes $47-50^{\circ} \mathrm{N}$ ), and (d) 11 stations in Southern Europe (latitudes less than $47^{\circ} \mathrm{N}$ ).

frequency in both space and time for VOC from the EMEP network. Most VOCs are only measured twice per week and there is lack of data from multiple stations during August 2003. Furthermore, it is difficult to make direct comparisons of the lumped VOC species in CBM-Z with measured VOC. Therefore, we compare two VOC species important for our analysis: (a) isoprene, a primary biogenic emission and (b) formaldehyde (HCHO), an oxygenated VOC that can result from primary anthropogenic emissions, but its dominant source in the atmosphere is via the oxidation of anthropogenic and biogenic VOC.

Figure 7 shows a time series of August $2003 \mathrm{NO}_{2}$ observations versus observations, spatially grouped in the same manner as the ozone evaluation (Fig. 5). This includes the "eight representative stations," where only one of these eight stations measures $\mathrm{NO}_{2}$ (ES09), Northern Europe (10 stations),
Central Europe (1 station) and Southern Europe (11 stations). In general, the model predicts a regular diurnal cycle with higher concentrations than observed. Additionally, the model frequently misses high-concentration events present in the observations. This is not surprising because the model's daily variability is driven by meteorology as emissions only vary on the monthly time scale. Observed values range from 4-12 ppb in Northern Europe, 4-20 ppb in Central Europe, and $1-7 \mathrm{ppb}$ in Southern Europe. At the ES09 station, the model over predicts $\mathrm{NO}_{2}$ concentrations by several ppb over most of the month and also slightly underestimates nighttime $\mathrm{NO}_{2}$ by $0.5-2 \mathrm{ppb}$. At the Northern European stations, the model overestimates daily maxima by $10-20 \mathrm{ppb}$, with reduced biases at the Central and Southern Europe stations. The single Central Europe site has the greatest $\mathrm{NO}_{2}$ concentrations (ranging up to $20 \mathrm{ppb}$ ) with decreasing values in 

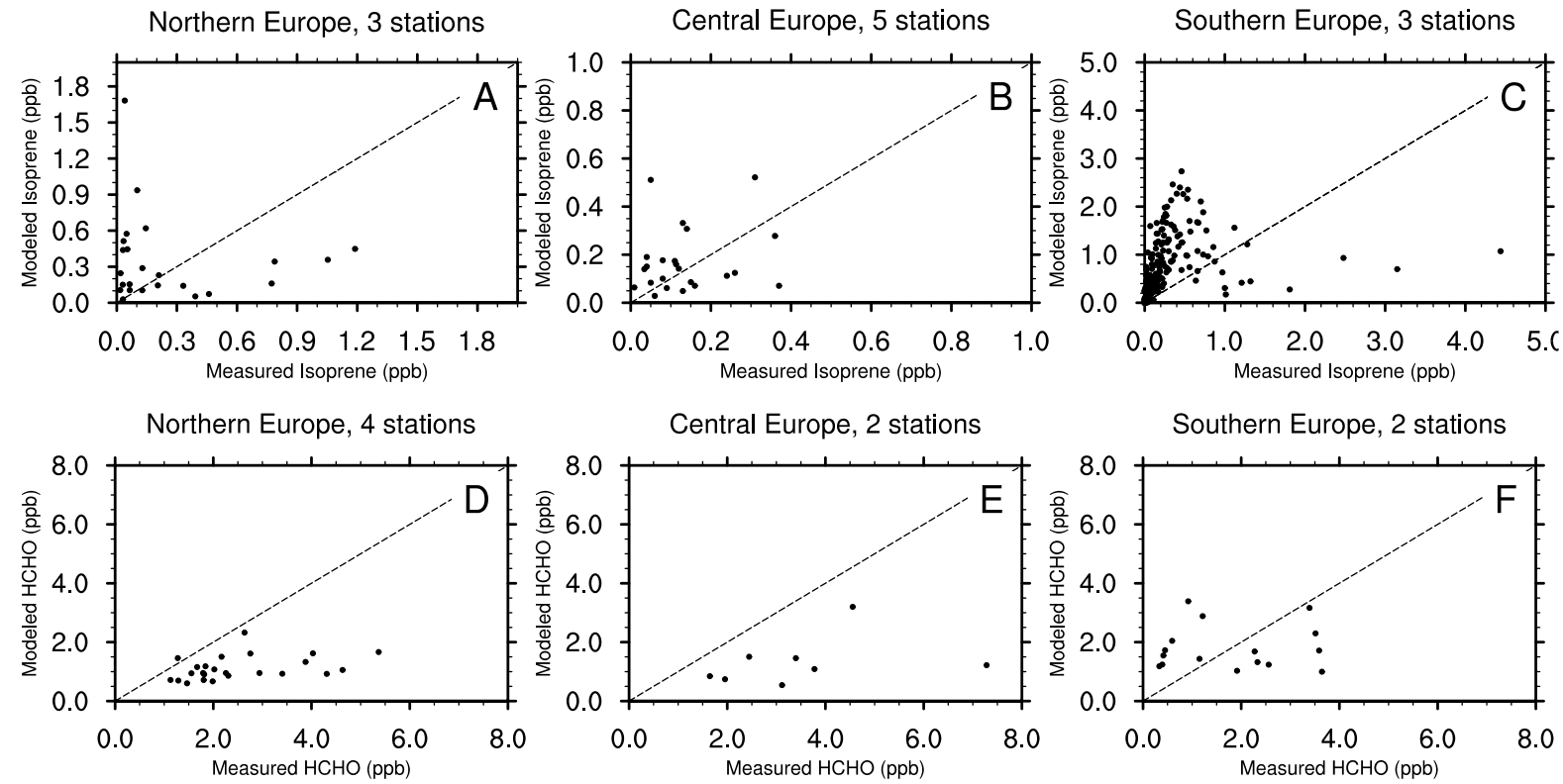

Fig. 8. Scatter plots of measured versus modelled isoprene (ppb) for (a) 3 stations in Northern Europe, (b) 5 stations in Central Europe and (c) 3 stations in Southern Europe, and measured versus modelled formaldehyde (ppb) for (d) 4 stations in Northern Europe, (e) 2 stations in Central Europe, and (f) 2 stations in Southern Europe.

Southern Europe, and the model reproduces these broader spatial patterns. As noted above, the goal of the development simulations presented here is to produce climatological simulations of ozone with monthly emissions, therefore, we expect that the model will have difficulty reproducing these daily events. We also note that many modelling studies find that observed $\mathrm{NO}_{2}$ is much higher than modelled, and this has been attributed to $\mathrm{NO}_{2}$ measurement errors (e.g., Dunlea et al., 2007; Lamsal et al., 2008), $\mathrm{NO}_{2}$ sampling location biases (e.g., sensors located very close to emission sources) and the effects of model grid cell resolution on the resulting $\mathrm{NO}_{2}$ chemistry (Valin et al., 2011). The biases presented here suggest that a higher time resolution than monthly emissions is likely needed to capture these specific ozone events. Despite these limitations, Fig. 7 indicates that the model generally represents the proper spatial range of $\mathrm{NO}_{2}$ concentrations and this likely leads to the good measured-modelled agreement of ozone concentrations as discussed in Sect. 3.3.

VOC measurements at the EMEP stations are more limited than $\mathrm{NO}_{2}$, with a total of 11 stations reporting VOC data and 8 stations reporting carbonyl data in our model domain. Because of these limits in space and time, scatter plots compare observed isoprene concentrations versus modelled concentrations at twelve stations in August 2003 (Fig. 8a-c) and observed $\mathrm{HCHO}$ concentrations versus modelled $\mathrm{HCHO}$ (Fig. 8d-f). Isoprene is a predominantly biogenically emitted species with online model emissions, meaning that RegCM temperature and radiation data is used to drive hourly emis- sion calculations. Observed isoprene concentrations range from 0-1.2 ppb in Northern Europe, 0-0.5 ppb in Central Europe and up to $4.5 \mathrm{ppb}$ in Southern Europe. The model captures these general regional trends, although $R^{2}$ values are extremely low. In Southern Europe, modelled concentrations are about a factor of two higher than observed. We attribute this model overestimate to the warm temperature bias present in RegCM-CHEM4, which can increase the amount of biogenic isoprene emitted due to the online emissions scheme.

Measured $\mathrm{HCHO}$ values range up to 6-8 ppb in Northern and Central Europe, with slightly lower values in the Southern Europe (up to 4 ppb) (Fig. 8d-f). Higher values in Northern and Central Europe suggest an anthropogenic oxidation component to observed concentrations, as these are collocated with many of the primary anthropogenic VOC emissions. In all regions, the model underestimates observed concentrations by a factor of 2-4. With only few ground-level observations to evaluate, it is difficult to pinpoint the cause of these discrepancies, but they suggest that oxidation in the model may be too slow particularly in the more urbanized regions of northern and central Europe.

\subsection{VOC and $\mathrm{NO}_{\mathrm{x}}$ sensitivity}

Past studies have evaluated the sensitivity of ozone formation in Europe to the two main ozone precursors and have noted that northwestern Europe is typically VOC-sensitive transitioning to $\mathrm{NO}_{\mathrm{x}}$-sensitive to the south (Beekman and 


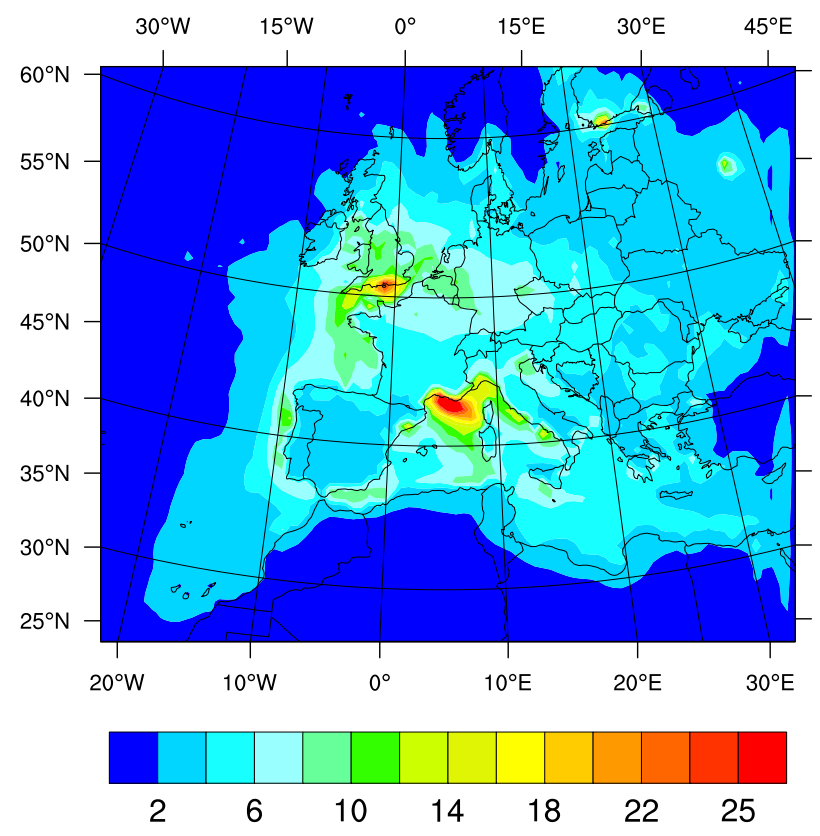

Fig. 9. Average August 14:00 (UT) 2003 concentration of $\mathrm{NO}_{\mathrm{y}}$ (ppb).

Vautard, 2010). To evaluate the model response to the ozone precursors and determine if we can replicate these regional sensitivities, we evaluate simulated $\mathrm{NO}_{\mathrm{y}}$ concentrations as a proxy for ozone sensitivity as it correlates well with other detailed sensitivity studies in Europe (Beekman and Vautard, 2010). Here we define $\mathrm{NO}_{\mathrm{y}}$ as the sum of $\mathrm{NO}_{2}+\mathrm{NO}+\mathrm{HNO}_{3}+\mathrm{PAN}$, where relatively high concentrations can provide an indicator of VOC-sensitive regions. Additional reactive nitrogen species (e.g., alkyl nitrates, isoprene nitrates, and higher order PAN analogues) would increase $\mathrm{NO}_{\mathrm{y}}$ by approximately $25 \%$ if included.

Previous studies have shown that $\mathrm{NO}_{\mathrm{x}}$-sensitive conditions are generally associated with low values of $\mathrm{NO}_{\mathrm{y}}$ during the afternoon (concurrent with the time of elevated $\mathrm{O}_{3}$ ) and that VOC-sensitive conditions are associated with higher $\mathrm{NO}_{\mathrm{y}}$ (Milford et al., 1994; Sillman and He, 2002; Beekman and Vautard, 2010). The $\mathrm{NO}_{\mathrm{y}}$ threshold for VOC- versus $\mathrm{NO}_{\mathrm{x}}$-sensitivity can vary depending on location, with interregional differences caused by the overall $\mathrm{VOC} / \mathrm{NO}_{\mathrm{x}}$ ratio, meteorological conditions and the influence of ozone advection. In the United States, VOC-sensitive conditions have been defined as $\mathrm{NO}_{\mathrm{y}}=11-50 \mathrm{ppb}$ and $\mathrm{NO}_{\mathrm{x}}$-sensitive locations displaying $\mathrm{NO}_{\mathrm{y}}=3-12 \mathrm{ppb}$ (Milford et al., 1994). In Europe, these values have been determined to be slightly lower than the United States and VOC-sensitive regimes have been noted as 6-13 ppb in southwestern Germany (Vogel et al., 1999) and ranging from 6-9 ppb depending on location in continental Europe (Beekman and Vautard, 2010).

Figure 9 shows the distribution of $\mathrm{NO}_{\mathrm{y}}$ at the peak of the ozone episode (average 14:00 UTC concentration in Au- gust 2003). High $\mathrm{NO}_{\mathrm{y}}$ concentrations are generally located near the main $\mathrm{NO}_{\mathrm{x}}$ sources in the model, including southern British Isles, the Benelux states and Western Germany as well as few locations in northern Italy and the south of France. This suggests that the model is VOC-sensitive in the southern portion of the British Isles and across some of Northern Europe, as noted in other studies (Beekmann and Vautard, 2010). $\mathrm{NO}_{\mathrm{y}}$ concentrations in Spain and the southern portion of Italy are lower (typically less than $6 \mathrm{ppb}$ ) suggesting $\mathrm{NO}_{\mathrm{x}}$-sensitivity in this region. The apparent plume of high $\mathrm{NO}_{\mathrm{y}}$ extending south into the Mediterranean from the coast of France is noteworthy. This plume corresponds to reduced $\mathrm{O}_{3}$ relative to the surrounding region and most likely represents slower formation of $\mathrm{O}_{3}$ in a high- $\mathrm{NO}_{\mathrm{x}}$ plume. The model emissions inventory slightly exaggerates the coastline emissions due to regridding from a $0.5^{\circ}$ rectilinear grid to the projected $60 \mathrm{~km}$ grid, resulting a slight shift in the emissions over water (Fig. 1a). Elevated $\mathrm{NO}_{\mathrm{x}}$ in urban plumes transported over water due to the combination of high $\mathrm{NO}_{\mathrm{x}}$ emissions near the shore and suppressed vertical mixing over water have been described previously (Sillman et al., 1993; Neuman et al., 2006). These plumes are generally VOC-sensitive, in contrast to the likely $\mathrm{NO}_{\mathrm{x}}$-sensitive conditions over the rest of the Mediterranean. Velchev et al. (2011) report instances of decreased $\mathrm{O}_{3}$ coincident with high aerosols found during ship-based measurements in the western Mediterranean, which they attribute to removal of $\mathrm{O}_{3}$ by $\mathrm{NO}_{\mathrm{x}}$ in high-emission regions near harbours. The observed instances were found immediately downwind of Marseilles and Barcelona, but relatively close to the urban centres. Therefore, this elevated $\mathrm{NO}_{\mathrm{y}}$ plume is likely a combination of emissions being shifted slightly away from the coastline and the subsequent meteorological effects of this shift.

In general, the distribution of $\mathrm{NO}_{\mathrm{y}}$ concentrations look similar to other regional chemistry models (e.g., Beekman and Vautard, 2010), with the exception of emissions along the southern coast of France extending out over the Mediterranean. This area has the highest $\mathrm{NO}_{\mathrm{y}}$ concentrations in the model domain and is likely due to the relatively high $\mathrm{NO}_{\mathrm{x}}$ source in the region from our selected inventory. Extreme temperature events such as the 2003 event may cause a shift in the VOC- $\mathrm{NO}_{\mathrm{x}}$ sensitivity of these regions as noted in Vieno et al. (2010). Overall, these results suggest that the model is simulating the proper photochemical regimes necessary to capture ozone formation.

\section{Climatological ozone simulation}

The 2003 European ozone event analysis presented in Sect. 3 indicates that the model simulates ozone well compared to observations for short-term (e.g., event-based) analysis. Here we evaluate results from a continuous six-year integration over the same domain to provide evidence of the RegCMCHEM's ability to perform long-term simulations of ozone. 

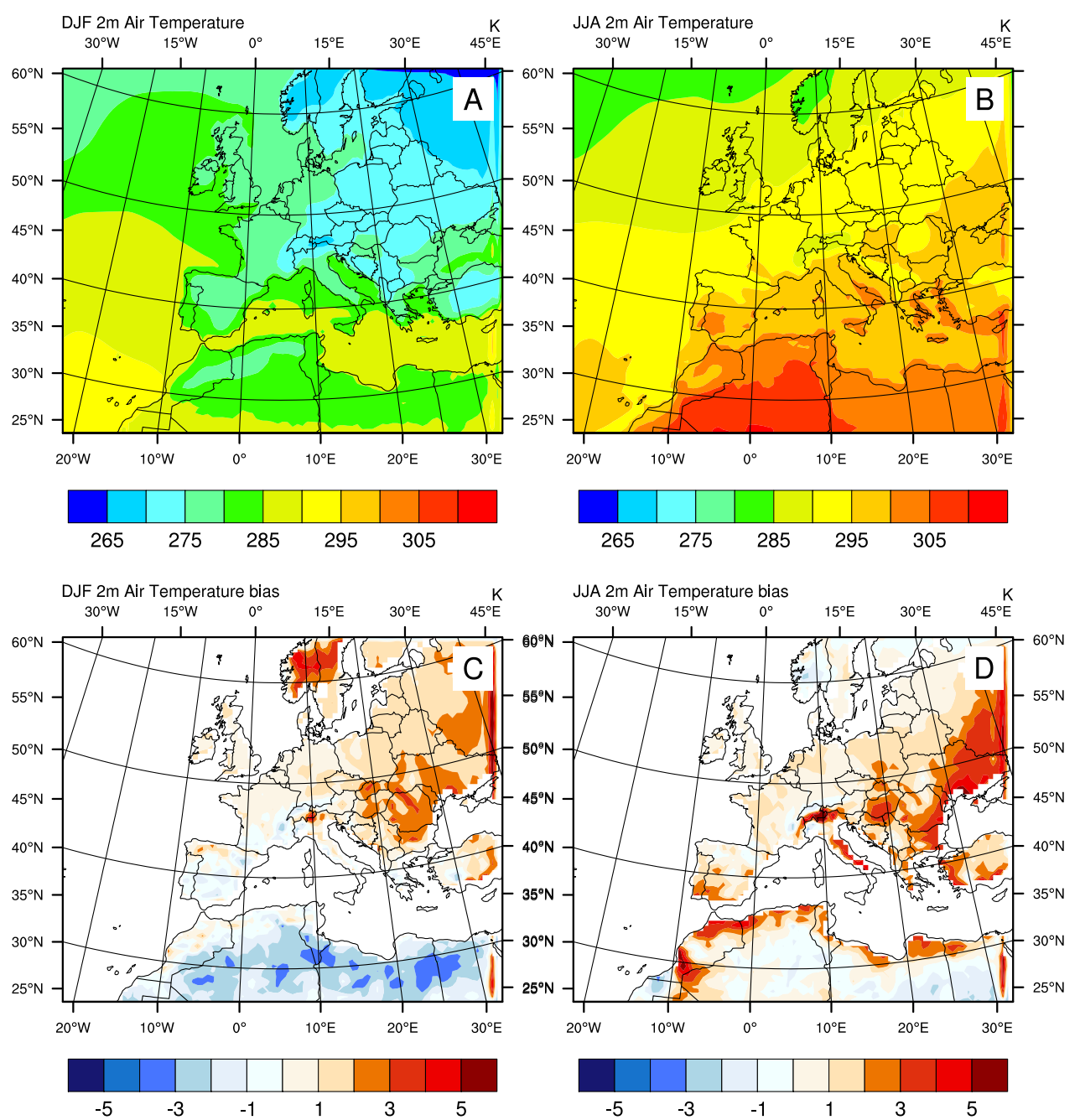

Fig. 10. (a) RegCM-CHEM modelled climatological average surface air temperature (K) for DJF (2000-2005) (b) JJA (2000-2005). Model temperature bias for (c) DJF and (d) JJA based on CRU data (Mitchell and Jones, 2005).

Modelled seasonal average surface air temperatures for winter (DJF) and summer (JJA) show the seasonal cycle of temperature (Fig. 10a, b), with modelled biases as compared to CRU gridded temperatures (Fig. 10c, d). Winter biases in continental Europe typically are less than $2 \mathrm{~K}$, with a warm bias in northern Scandinavia and Eastern Europe of 3-5 K and a slight cool bias over northern Africa of 3-4 K. In summer (Fig. 10d), a slight warm bias (less than $2 \mathrm{~K}$ ) exists throughout continental Europe, with a stronger warm bias over the Alps and central Italy (3-6 K). Overall, however, the temperature biases in RegCM remain small over much of the ozone evaluation region with the exception of the highaltitude areas in the Alps. Past studies with older model versions (RegCM3) have a persistent cool bias (Giorgi et al., 2004; Zanis et al., 2009; Patarcic and Brankovic, 2012), yet RegCM4 simulations show a warm JJA bias in northern Eu- rope and minimal bias in southern Europe (Giorgi et al., 2012) similar to these simulations.

To evaluate the modelled ozone concentrations from the long-term climate simulations, we implement the groundbased EMEP ozone observations as described in Sect. 3, including the eight representative stations, northern Europe (30 stations), central Europe (28 stations) and southern Europe ( 25 stations). We compare modelled monthly average daily maxima with ground-based EMEP observations over the six years of analysis (2000-2005) for each of the regions (Fig. 11). For the eight representative stations, the model over predicts ozone concentrations in most of the summers except for the 2003 heat wave event, where observed and modelled concentrations have similar average monthly summer maxima (70 ppb). Modelled winter concentrations are within $5 \mathrm{ppb}$ of observed values ( $\sim 30 \mathrm{ppb})$. In the Northern Europe region, the observations exhibit a bi-modal peak in the 
Interannual Monthly Averages of Daily Max, 2000-2005
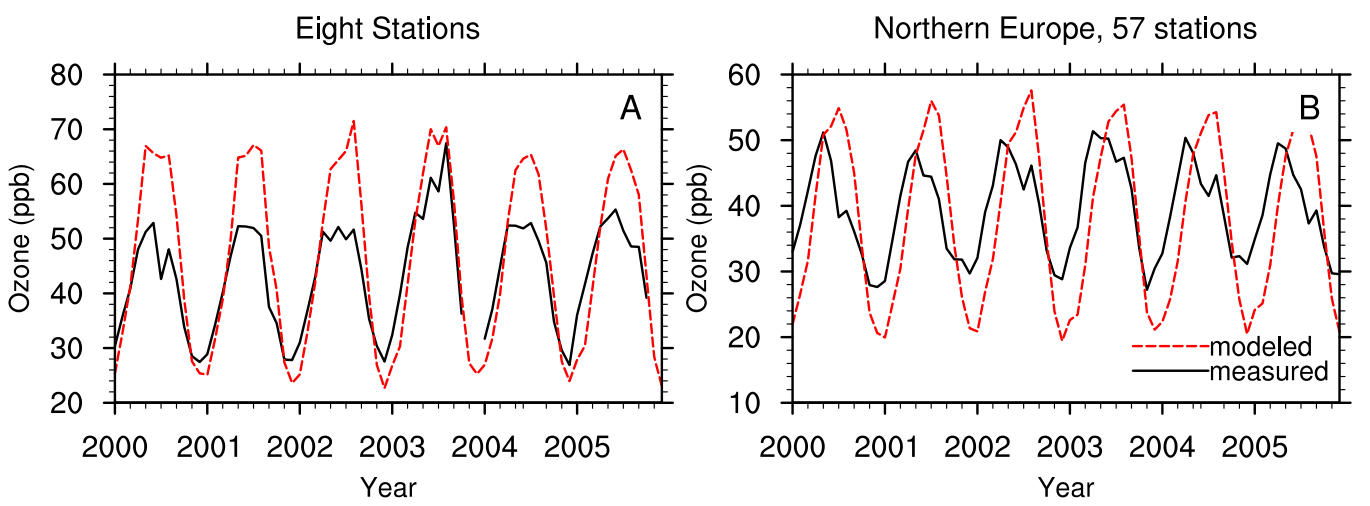

Central Europe, 28 stations

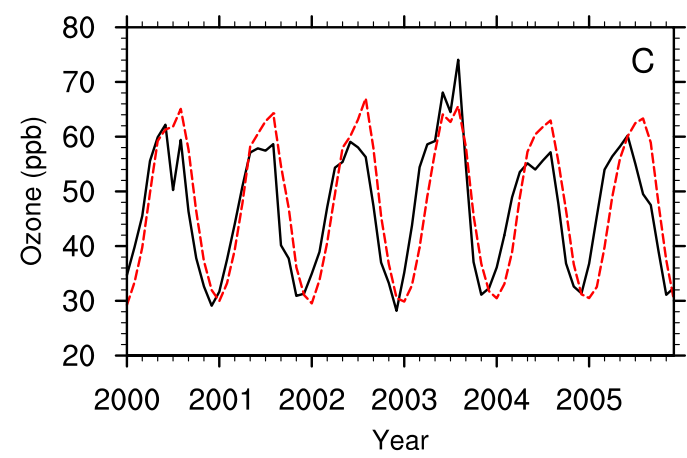

Southern Europe, 25 stations

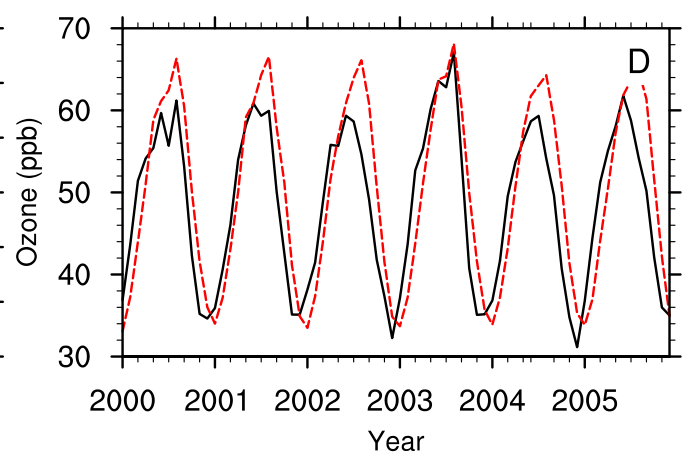

Fig. 11. Monthly average of daily maximum surface ozone concentrations (ppb) as measured (black) and modelled (red) for (a) eight representative EMEP stations (see text for locations), (b) 57 EMEP stations in Northern Europe, (c) 28 EMEP stations in Central Europe and (d) 25 stations in Southern Europe.

ozone maxima, with the highest concentrations in April (up to $50 \mathrm{ppb}$ ) followed by second maxima in July. The model does not reproduce this bi-modal nature of the seasonal cycle and predicts a single seasonal maximum in June. The modelled summer ozone bias improves in the Central and Southern Europe stations, with measured and modelled averaged monthly daily maximum ozone concentrations typically within $5 \mathrm{ppb}$. In Central Europe, the model predicts slightly higher concentrations than observed, particularly in the latter half of the summer. As with the Northern Europe region, the model exhibits a slight shift to the month of peak summer concentrations, with the modelled seasonal cycle lagging the observed cycle by approximately one month. In Southern Europe, the model also exhibits a slight bias to the summertime concentrations of about $5 \mathrm{ppb}$ and the same seasonal shift to the ozone concentrations. We note that these results differ from other seasonal evaluations of ozone with RegCM, where Zanis et al. (2011) underestimated monthly summer values in all regions, whereas our results indicate an over prediction of summer ozone. While both studies use the RegCM meteorological to drive meteorology, we note that we are using a different chemical mechanism, land surface model and biogenic VOC emissions inventory than Zanis et al. (2011) that may lead to some different temperature responses particularly in southern Europe.

Interestingly, the modelled seasonal cycle exhibits slight interannual variability compared to the observations. The unusual heat wave event of August 2003 is evident in the observations, particularly at the eight representative sites and the Central Europe and Southern Europe stations. While the model simulates the ozone event of this year fairly well, concentrations in other years are frequently higher than observed, particularly at several of the Central European stations. We note the lack of interannual variability in the chemical boundary conditions in these simulations (see Sect. 2.7), and it is possible that this is a contributing factor. This lack of strong interannual variability is currently being explored with separate simulations in the European and other regional domains.

\section{Conclusions and recommendations}

In this paper, we describe a newly developed, online, integrated chemistry-climate model (RegCM-CHEM4) designed to conduct high-resolution, long-term simulations of climate and tropospheric ozone. We provide evidence that the 
RegCM-CHEM4 can simulate event-driven ozone concentrations in August 2003 as well as a long-term seasonal cycle of ozone. For the August 2003 event analysis, we find that the model is able to reproduce the overall diurnal cycle of ozone and the sharp shifts in concentrations due to meteorological conditions. Analysis of the full six years of simulation indicates that the coupled chemistry-climate model can reproduce the seasonal cycle of ozone, with an overestimation of ozone in the non-event years of 5-15 ppb depending on the geographic region.

In this manuscript, we neglect the feedbacks from the radiative forcing of ozone, essentially decoupling the atmospheric chemistry and dynamics, a feedback that will be discussed in subsequent manuscripts. Future model evaluation tasks will include an assessment of the radiative forcing produced by ozone in these simulations and the impacts of online chemistry on the simulation of atmospheric aerosols in the RegCM-CHEM4 aerosol tracer model. The simulations presented here highlight shortcomings with the model boundary conditions that may affect our ability to simulate the interannual variability of ozone, including the effects of using non-climatological chemical boundary conditions for decadal scale simulations. Future simulations will test the effects of using time-variant boundary conditions at the lateral and top boundaries. For event-based simulations, the evaluation of ozone precursors suggests that higher time resolution emissions inventories for key precursors such as $\mathrm{NO}_{\mathrm{x}}$ are needed, and we are currently developing a new emissions pre-processor to develop emissions inventories at weekly to hourly time scales. An additional future model development task is to include the addition of a full thermodynamic aerosol model to replace or use in conjunction with the existing RegCM4 aerosol transport scheme (Giorgi et al., 2012), and the development of wet removal by the cumulus precipitation parameterization.

Despite these model limitations and the need for additional simulations and evaluation over other regions of the globe, the results presented here show that the model can perform accurate simulations of regional ozone for use in chemistryclimate studies. Future studies will investigate the model over other domains and conditions, with the intent of performing decadal scale simulations of ozone, model intercomparisons with other regional chemistry-climate models, and improving the representation of interannual ozone variability.

Acknowledgements. This work was supported through a grant from the US-Egypt Joint Board on Scientific and Technological Collaboration to A. Zakey and A. L. Steiner (NSF AGS0809255) and the European Union's Seventh Framework Programme (FP/2007-2011) within the project MEGAPOLI (grant agreement no. 212520). We thank the International Centre for Theoretical Physics, Trieste, Italy and the Earth System Physics group for providing administrative and computational support for this project. Participation of R. A. Zaveri in this study was partially supported by the US Department of Energy's (DOE) Atmospheric System Research (ASR) programme. We also gratefully acknowledge Louisa
Emmons at NCAR for providing MOZART chemical boundary conditions for these simulations.

Edited by: A. Lauer

\section{References}

Andersson, C. and Engardt, M.: European ozone in a future climate: Important changes in dry deposition and isoprene emissions, J. Geophys. Res., 115, D02303, doi:10.1029/2008JD011690, 2010.

Barth, M. C., Sillman, S., Hudman, R., Jacobson, M. Z., Kim, C.H., Monod, A., and Liang, J.: Summary of the cloud chemistry modelling intercomparisons: photochemical box model simulation, J. Geophys. Res., 108, 4214, doi:10.1029/2002JD002673, 2002.

Beekmann, M. and Vautard, R.: A modelling study of photochemical regimes over Europe: robustness and variability, Atmos. Chem. Phys., 10, 10067-10084, doi:10.5194/acp-1010067-2010, 2010.

Beniston, M. and Diaz, H. F.: The 2003 heat wave as an example of summers in a greenhouse climate? Observations and climate model simulations for Basel, Switzerland, Global Planet. Change, 44, 73-81, 2004.

Black, E., Blackburn, M., Harrison, G., Hoskins, B., and Methven, J.: Factors contributing to the summer 2003 European heat wave, Weather, 59, 217-223, doi:10.1256/wea.74.04, 2004.

Chang, J., Chang, J. S., Brost, R. A., Isaksen, I. S. A., Madronich, S., Middleton, P., Stockwell, W. R., and Walcek, C.: A threedimensional Eulerian and deposition model, Physical concepts and formulation, J. Geophys. Res., 92, 14681-14700, 1987.

Chapman, E. G., Gustafson Jr., W. I., Easter, R. C., Barnard, J. C., Ghan, S. J., Pekour, M. S., and Fast, J. D.: Coupling aerosolcloud-radiative processes in the WRF-Chem model: Investigating the radiative impact of elevated point sources, Atmos. Chem. Phys., 9, 945-964, doi:10.5194/acp-9-945-2009, 2009.

Chen, J., Avise, J., Lamb, B., Salathé, E., Mass, C., Guenther, A., Wiedinmyer, C., Lamarque, J.-F., O’Neill, S., McKenzie, D., and Larkin, N.: The effects of global changes upon regional ozone pollution in the United States, Atmos. Chem. Phys., 9, 1125 1141, doi:10.5194/acp-9-1125-2009, 2009.

Dee, D. P., Uppala, S. M., Simmons, A. J., Berrisford, P., Poli, P., Kobayashi, S., Andrae, U., Balmaseda, M. A., Balsamo, G., Bauer, P., Bechtold, P., Beljaars, A. C. M., van de Berg, L., Bidlot, J., Bormann, N., Delsol, C., Dragani, R., Fuentes, M., Geer, A. J., Haimberger, L., Healy, S. B., Hersbach, H., Holm, E. V., Isaksen, L., Kallberg, P., Kohler, M., Matricardi, M., McNally, A. P., Monge-Sanz, B. M., Morcrette, J. J., Park, B. K., Peubey, C., de Rosnay, P., Tavolato, C., Thepaut, J. N., and Vitart, F.: The ERA-Interim reanalysis: configuration and performance of the data assimilation system, Q. J. Roy. Meteorol. Soc., 137, 553-597, 2011.

Delle Monache, L. and Stull, R.: An ensemble air-quality forecast over western Europe during an ozone episode, Atmos. Environ., 37, 3469-3474, 2003.

Dunlea, E. J., Herndon, S. C., Nelson, D. D., Volkamer, R. M., San Martini, F., Sheehy, P. M., Zahniser, M. S., Shorter, J. H., Wormhoudt, J. C., Lamb, B. K., Allwine, E. J., Gaffney, J. S., Marley, N. A., Grutter, M., Marquez, C., Blanco, S., Cardenas, B., Retama, A., Ramos Villegas, C. R., Kolb, C. E., Molina, L. T., 
and Molina, M. J.: Evaluation of nitrogen dioxide chemiluminescence monitors in a polluted urban environment, Atmos. Chem. Phys., 7, 2691-2704, doi:10.5194/acp-7-2691-2007, 2007.

Emmons, L. K., Walters, S., Hess, P. G., Lamarque, J.-F., Pfister, G. G., Fillmore, D., Granier, C., Guenther, A., Kinnison, D., Laepple, T., Orlando, J., Tie, X., Tyndall, G., Wiedinmyer, C., Baughcum, S. L., and Kloster, S.: Description and evaluation of the Model for Ozone and Related chemical Tracers, version 4 (MOZART-4), Geosci. Model Dev., 3, 43-67, doi:10.5194/gmd3-43-2010, 2010.

Fast, J. D. and Heilman, W. E.: Simulated sensitivity of seasonal ozone exposure in the Great Lakes region to changes in anthropogenic emissions in the presence of interannual variability, Atmos. Environ., 39, 5291-5306, 2005.

Fast, J. D., Zaveri, R. A., Bian, X., Chapman, E. G., and Easter, R. C.: Effect of regional-scale transport on oxidants in the vicinity of Philadelphia during the 1999 NE-OPS field campaign, J. Geophys. Res., 107, 4330, doi:10.1029/2001JD000980, 2002.

Fast, J. D., Gustafson Jr., W. I., Easter, R. C., Zaveri, R. A., Barnard, J. C., Chapman, E. G., Grell, G. A., and Peckham, S. E.: Evolution of ozone, particulates, and aerosol direct radiative forcing in the vicinity of Houston using a fully coupled meteorology-chemistry-aerosol model, J. Geophys. Res., 111, D21305, doi:10.1029/2005JD006721, 2006.

Fink, A. H., Brücher, T., Krüger, A., Lechebusch, C., Pinto, J. G., and Ulbrich, U.: The 2003 European summer heatwaves and drought-synoptic diagnosis and impacts, Weather, 59, 295-261, doi:10.1256/wea.73.04, 2004.

Forkel, R. and Knoche, R.: Regional climate change and its impact on photooxidant concentrations in Southern Germany: simulations with a coupled regional climate-chemistry model, J. Geophys. Res., 111, D12302, doi:10.1029/2005JD006748, 2006.

Gery, M. W., Whitten, G. Z., Killus, J. P., and Dodge, M. C.: A photochemical kinetic mechanism for urban and regional scale computer modelling, J. Geophys. Res., 94, 12925-12956, 1989.

Giorgi, F. and Mearns, L. O.: Introduction to special section: regional climate modeling revisited, J. Geophys. Res., 104, 63356352, 1999.

Giorgi, F., Pal, J. S., Bi, X., Sloan, L., Elguindi, N., and Solmon, F.: Introduction to the TAC Special Issue: the RegCNET network, Theor. Appl. Climatol., 86, 1-4, 2006.

Giorgi, F. and Meleux, F.: Modelling the regional effects of climate change on air quality, C. R. Geoscience, 339, 721-733, 2007.

Giorgi, F., Coppola, E., Solmon, F., Marioitti, L., Sylla, M. B., Bi, X., Elguindi, N., Diro, G. T., Nair, V., Giuliani, G., Cozzini, S., Guettler, I., O'Brien, T. A., Tawfik, A. B., Shalapy, A., Zakey, A. S., Steiner, A. L., Stordal, F., Sloan, L. C., and Brankovic, C.: RegCM4: Model description and preliminary tests over multiple CORDEX domains, Clim. Res., 52, 7-29, doi:10.3354/cr01018, 2012.

Grell, G. A.: Prognostic evaluation of assumptions used by cumulus parameterizations, Mon. Weather Rev., 121, 764-787, 1993.

Grell, G. A., Peckham, S. E., Schmitz, R., McKeen, S. A., Frost, G., Skamarock, W. C., and Eder, B.: Fully coupled online chemistry within the WRF model, Atmos. Environ., 39, 6957-6975, 2005.

Guenther, A., Karl, T., Harley, P., Wiedinmyer, C., Palmer, P. I., and Geron, C.: Estimates of global terrestrial isoprene emissions using MEGAN (Model of Emissions of Gases and Aerosols from
Nature), Atmos. Chem. Phys., 6, 3181-3210, doi:10.5194/acp-63181-2006, 2006.

Hedegaard, G. B., Brandt, J., Christensen, J. H., Frohn, L. M., Geels, C., Hansen, K. M., and Stendel, M.: Impacts of climate change on air pollution levels in the Northern Hemisphere with special focus on Europe and the Arctic, Atmos. Chem. Phys., 8, 3337-3367, doi:10.5194/acp-8-3337-2008, 2008.

Hodzic, A., Vautard, R., Chepfer, H., Goloub, P., Menut, L., Chazette, P., Deuzé, J. L., Apituley, A., and Couvert, P.: Evolution of aerosol optical thickness over Europe during the August 2003 heat wave as seen from CHIMERE model simulations and POLDER data, Atmos. Chem. Phys., 6, 1853-1864, doi:10.5194/acp-6-1853-2006, 2006.

Hogrefe, C., Hao, W., Zalewsky, E. E., Ku, J.-Y., Lynn, B., Rosenzweig, C., Schultz, M. G., Rast, S., Newchurch, M. J., Wang, L., Kinney, P. L., and Sistla, G.: An analysis of long-term regional-scale ozone simulations over the Northeastern United States: variability and trends, Atmos. Chem. Phys., 11, 567-582, doi:10.5194/acp-11-567-2011, 2011.

Holtslag, A. A. M. and Boville, B. A.: Local versus nonlocal boundary-layer diffusion in a global climate model, J. Climate, 6, 1825-1842, 1993.

Horowitz, L. W., Walters, S., Mauzerall, D. L., Emmons, L. K., Rasch, P. J., Granier, C., Tie, X., Lamarque, J., Schultz, M. G., Tyndall, G. S., Orlando, J. J., and Brasseur, G. P.: A global simulation of tropospheric ozone and related tracers: description and evaluation of MOZART, version 2, J. Geophys. Res., 108, D24, doi:10.1029/2002JD002853, 2003.

Huszar, P., Juda-Rezler, K., Halenka, T., Chervenkov, H., Syrakov, D., Krüger, B. C., Zanis, P., Melas, D., Katragkou, E., Reizer, M., Trapp, W., and Belda, M.: Effects of climate change on ozone and particulate matter over Central and Eastern Europe, Clim. Res., 50, 51-68, doi:10.3354/cr01036, 2012.

IPCC: Intergovernmental Panel On Climate Change, Climate Change 2007: The Physical Science Basis. Contribution of Working Group I to the Fourth Assessment Report of the IPCC, Cambridge University Press, Cambridge, UK, and New York, USA, 2007.

Jacob, D. J. and Winner, D. A.: Effect of climate change on air quality, Atmos. Environ., 43, 51-63, doi:10.1016/j.atmosenv.2008.09.051, 2009.

Jacobson, M. Z., Lu, R., Turco, R. P., and Toon, O. B.: Development and application of a new air pollution modeling system - Part I: gas-phase simulation, Atmos. Environ., 30, 1939-1963, 1996.

Jacobson, M. Z.: Development and application of a new air pollution modeling system - Part II: aerosol module structure and design, Atmos. Environ., 31, 131-144, 1997a.

Jacobson, M. Z.: Development and application of a new air pollution modeling system - Part III: aerosol-phase simulation, Atmos. Environ., 31, 587-608, 1997b.

Jiang, G. and Fast, J. D.: Modeling the effects of VOC and $\mathrm{NO}_{\mathrm{x}}$ emission sources on ozone formation in Houston during the TexAQS 2000 field campaign, Atmos. Environ., 38, 5071- 5085, 2004.

Katragkou, E., Zanis, P., Kioutsioukis, I., Tegoulias, I., Melas, D., Krüger, B. C., and Coppola, E.: Future climate change impacts on summer surface ozone from regional climate-air quality simulations over Europe, J. Geophys. Res., 116, D22307, doi:10.1029/2011JD015899, 2011. 
Kiehl, J. T., Hack, J. J., Bonan, G. B., Boville, B. A., Breigleb, B. P., Williamson, D., and Rasch, P.: Description of the NCAR community climate model (CCM3), Tech. Rep. NCAR/TN420+STR, National Center for Atmospheric Research, 1996.

Krüger, B. C., Katragkou, E., Tegoulias, I., Zanis, P., Melas, D., Coppola, E., Rauscher, S., Huszar, P., and Halenka, T.: Regional photochemical model calculations for Europe concerning ozone levels in a changing climate, Q. J. Hung. Met. Serv., 112, 285300, 2008.

Lamarque, J.-F., Bond, T. C., Eyring, V., Granier, C., Heil, A., Klimont, Z., Lee, D., Liousse, C., Mieville, A., Owen, B., Schultz, M. G., Shindell, D., Smith, S. J., Stehfest, E., Van Aardenne, J., Cooper, O. R., Kainuma, M., Mahowald, N., McConnell, J. R., Naik, V., Riahi, K., and van Vuuren, D. P.: Historical (1850-2000) gridded anthropogenic and biomass burning emissions of reactive gases and aerosols: methodology and application, Atmos. Chem. Phys., 10, 7017-7039, doi:10.5194/acp10-7017-2010, 2010

Lamsal, L. N., Martin, R. V., van Donkelaar, A., Steinbrecher, M., Celarier, E. A., Bucsela, E., Dunlea, E. J., and Pinto, J. P.: Ground-level nitrogen dioxide concentrations inferred from the satellite-borne Ozone Monitoring Instrument, J. Geophys. Res., 113, D16308, doi:10.1029/2007JD009235, 2008.

Langner, J., Bergström, R., and Foltescu, V.: Impact of climate change on surface ozone and deposition of sulphur and nitrogen in Europe, Atmos. Environ., 39, 1129-1141, 2005.

Leibensperger, E. M., Mickley, L. J., and Jacob, D. J.: Sensitivity of US air quality to mid-latitude cyclone frequency and implications of 1980-2006 climate change, Atmos. Chem. Phys., 8, 7075-7086, doi:10.5194/acp-8-7075-2008, 2008.

Li, J., Wang, Z., Akimoto, H., Yamaji, K., Takigawa, M., Pochanart, P., Liu, Y., Tanimoto, H., and Kanaya, Y.: Nearground ozone source attributions and outflow in central eastern China during MTX2006, Atmos. Chem. Phys., 8, 7335-7351, doi:10.5194/acp-8-7335-2008, 2008.

Liao, K.-J., Tagaris, E., Manomaiphiboon, K., Wang, C., Woo, J.H., Amar, P., He, S., and Russell, A. G.: Quantification of the impact of climate uncertainty on regional air quality, Atmos. Chem. Phys., 9, 865-878, doi:10.5194/acp-9-865-2009, 2009.

Luo, G. and Yu, F.: Simulation of particle formation and number concentration over the Eastern United States with the WRFChem + APM model, Atmos. Chem. Phys., 11, 11521-11533, doi:10.5194/acp-11-11521-2011, 2011.

Madronich, S. and Flocke, S.: The role of solar radiation in atmospheric chemistry; in: Handbook of Environmental Chemistry, edited by: Boule, P., Springer-Verlag, New York, 1-26, 1999.

Meleux, F., Solmon, F., and Giorgi, F.: Increase in summer European ozone amounts due to climate change, Atmos. Environ., 41, 7577-7587, 2007.

Milford, J., Gao, D., Sillman, S., Blossey, P., and Russell, A. G.: Total reactive nitrogen $\left(\mathrm{NO}_{\mathrm{y}}\right)$ as an indicator for the sensitivity of ozone to $\mathrm{NO}_{\mathrm{x}}$ and hydrocarbons, J. Geophys. Res., 99, 35333542, 1994.

Mitchell, T. D. and Jones, P. D.: An improved method of constructing a database of monthly climate observations and associated high-resolution grids, Int. J. Climatol., 25, 693-712, doi:10.1002/joc.1181, 2005.

NASA: Terrestrial Environment (climatic) criteria handbook for use in aerospace vehicle development, NASA-HDBK-1001,
11 August 2000.

Neuman, J. A., Parrish, D. D., Trainer, M., Ryerson, T. B., Holloway, J. S., Nowak, J. B., Swanson, A., Flocke, F., Roberts, J. M., Brown, S. S., Stark, H., Sommariva, R., Stohl, A., Peltier, R., Weber, R., Wollny, A. G., Sueper, D. T., Hubler, G., and Fehsenfeld, F. C.: Reactive nitrogen transport and photochemistry in urban plumes over the North Atlantic Ocean, J. Geophys. Res., 111, D23S54, doi:10.1029/2005JD007010, 2006.

Ordóñez, C., Mathis, H., Furger, M., Henne, S., Hüglin, C., Staehelin, J., and Prévôt, A. S. H.: Changes of daily surface ozone maxima in Switzerland in all seasons from 1992 to 2002 and discussion of summer 2003, Atmos. Chem. Phys., 5, 1187-1203, doi:10.5194/acp-5-1187-2005, 2005.

Oleson, K. W., Niu, G.-Y., Yang, Z.-L., Lawrence, D. M., Thornton, P. E., Lawrence, P. J., Stockli, R., Dickinson, R. E., Bonan, G. B., Levis, S., Dai, A., and Qian, T.: Improvements to the Community Land Model and their impact on the hydrological cycle, J. Geophys. Res., 113, G01021, doi:10.1029/2007JG000563, 2008.

Pal, J. S., Small, E. E., and Eltahir, E. A. B.: Simulation of regionalscale water and energy budgets: representation of subgrid cloud and precipitation processes within RegCM, J. Geophys. Res.Atmos., 105, 29579-29594, 2000.

Pal, J. S., Giorgi, F., Bi, X., Elguindi, N., Solmon, F., Gao, X. J., Francisco, R., Zakey, A., Winter, J., Ashfaq, M., Syed, F., Bell, J., Diffenbaugh, N., Karmacharya, J., Konare, A., MartinezCastro, D., Porfirio da Rocha, R., Sloan, L., and Steiner, A.: Regional climate modeling for the developing world: The ICTP RegCM3 and RegCNET, B. Am. Meteorol. Soc., 88, 1395-1409, 2007.

Patarcic, M. and Brankovic, C: Skill of 2-m Temperature Seasonal Forecasts over Europe in ECMWF and RegCM Models, Mon Wea. Rev., 140, 1326-1346, 2012.

Poupkou, A., Giannaros, T., Markakis, K., Kioutsioukis, I., Curci, G., Melas, D., and Zerefos, C.: A model for European biogenic volatile organic compound emissions: software development and first validation, Environ. Modell. Softw., 25, 1845- 1856, 2010.

Qian, Y. and Giorgi, F.: Interactive coupling of regional climate and sulfate aerosol models over astern Asia, J. Geophys. Res., 104, 6477-6499, 1999.

Santese, M., Perrone, M. R., Zakey, A. S., De Tomasi, F., and Giorgi, F.: Modeling of Saharan dust outbreaks over the Mediterranean by RegCM3: case studies, Atmos. Chem. Phys., 10, 133156, doi:10.5194/acp-10-133-2010, 2010.

Schär, C., Vidale, P. L., Lüthi, D., Frei, C., Häberli, C., Liniger, M. A., and Appenzeller, C.: The role of increasing temperature variability in European summer heatwaves, Nature, 427, 332 336, 2004.

Sillman, S.: A numerical solution for equations of tropospheric chemistry based on an analysis of sources and sinks of odd hydrogen, J. Geophys. Res., 96, 20735-20744, 1991.

Sillman, S. and He, D.: Some theoretical results concerning O3$\mathrm{NO}_{\mathrm{X}}$-VOC chemistry and $\mathrm{NO}_{\mathrm{X}}-\mathrm{VOC}$ indicators, J. Geophys. Res., 107, D22, 4659, doi:10.1029/2001JD001123, 2002.

Sillman, S., Samson, P. J., and Masters, J. M.: Ozone formation in urban plumes transported over water: photochemical model and case studies in the Northeastern and Midwestern US, J. Geophys. Res., 98, 12687-12699, 1993. 
Solmon, F., Giorgi, F., and Liousse, C.: Aerosol modelling for regional climate studies: application to anthropogenic particles and evaluation over a European/African domain, Tellus B, 58, 51-72, 2006.

Solberg, S., Hov, Ø., Søvde, A., Isaksen, I. S. A., Coddeville, P., De Backer, H., Forster, C., Orsolini, Y., and Uhse, K.: European surface ozone in the extreme summer 2003, J. Geophys. Res., 113, D7, doi:10.1029/2007JD009098, 2008.

Stamnes, K., Henriksen, K., and Østensen, P.: Simultaneous measurement of UV radiation received by the biosphere and total ozone amount, Geophys. Res. Lett., 15, 784-787, 1988.

Steinbrecher, R., Smiatek, G., Köble, R., Seufert, G., Theloke, J., Hauff, K., Ciccioli, P., Vautard, R., and Curci, G.: Intra- and inter-annual variability of VOC emissions from natural and seminatural vegetation in Europe and neighbouring countries, Atmos. Environ., 43, 1380-1391, doi:10.1016/j.atmosenv.2008.09.072, 2009.

Steiner, A. L., Tonse, S., Cohen, R. C., Goldstein, A. H., and Harley, R. A.: The influence of future climate and emissions on regional air quality in California, J. Geophys. Res., 111, D18303, doi:10.1029/2005JD006935, 2006.

Stevenson, D. S., Doherty, R. M., Sanderson, M. G., Johnson, C. E., Collins, W. J., and Derwent, R. G.: Impacts of climate change and variability on tropospheric ozone and its precursors, Faraday Discuss., 130, 41-57, 2005.

Struzewska, J. and Kaminski, J. W.: Formation and transport of photooxidants over Europe during the July 2006 heat wave - observations and GEM-AQ model simulations, Atmos. Chem. Phys., 8, 721-736, doi:10.5194/acp-8-721-2008, 2008.

Szopa, S., Hauglustaine, D. A., Vautard, R., and Menut, L.: Future global tropospheric ozone changes and impact on European air quality, Geophys. Res. Lett., 33, L14805, doi:10.1029/2006GL025860, 2006.

Tawfik, A. B. and Steiner, A. L.: The role of soil ice in landatmosphere coupling over the United States: a soil moistureprecipitation winter feedback mechanism, JGR Atmos., 116, D02113, doi:10.1029/2010JD014333, 2011.

Tawfik, A. B., Stöckli, R., Goldstein, A. H., Pressley, S. L., and Steiner, A. L.: Quantifying the contribution of environmental factors to isoprene flux interannual variability, Atmos. Environ., 43, 216-224, 2012.

van Loon, M., Vautard, R., Schaap, M., Bergström, R., Bessagnet, B., Brandt, J., Builtjes, P. J. H., Christensen, J. H., Cuvelier, K., Graf, A., Jonson, J. E., Krol, M., Langner, J., Roberts, P., Rouil, L., Stern, R., Tarrasón, L., Thunis, P., Vignati, E., White, L., and Wind, P.: Evaluation of long-term ozone simulations from seven regional air quality models and their ensemble average, Atmos. Environ., 41, 2083-2097, 2007.

Valin, L. C., Russell, A. R., Hudman, R. C., and Cohen, R. C.: Effects of model resolution on the interpretation of satellite $\mathrm{NO}_{2}$ observations, Atmos. Chem. Phys., 11, 11647-11655, doi:10.5194/acp-11-11647-2011, 2011.

Vautard, R., Honoré, C., Beekmann, M., and Rouil, L.: Simulation of ozone during the August 2003 heat wave and emission control scenarios, Atmos. Environ., 39, 2957-2967, 2005.

Vautard, R., Schaap, M., Bergström, R., Bessagnet, B., Brandt, J., Builtjes, P. J. H., Christensen, J. H., Cuvelier, C., Foltescu, V., Graff, A., Kerschbaumer, A., Krol, M., Roberts, P., Rouill, L., Stern, R., Tarrason, L., Thunis, P., Vignati, E., and Wind, P.: Skill and uncertainty of a regional air quality model ensemble, Atmos. Environ., 43, 4822-4832, 2009.

Velchev, K., Cavalli, F., Hjorth, J., Marmer, E., Vignati, E., Dentener, F., and Raes, F.: Ozone over the Western Mediterranean Sea - results from two years of shipborne measurements, Atmos. Chem. Phys., 11, 675-688, doi:10.5194/acp-11-675-2011, 2011.

Vieno, M., Dore, A. J., Stevenson, D. S., Doherty, R., Heal, M. R., Reis, S., Hallsworth, S., Tarrason, L., Wind, P., Fowler, D., Simpson, D., and Sutton, M. A.: Modelling surface ozone during the 2003 heat-wave in the UK, Atmos. Chem. Phys., 10, 7963-7978, doi:10.5194/acp-10-7963-2010, 2010.

Vogel, B., Riemer, N., Vogel H., and Fiedler, F.: Findings on $\mathrm{NOy}$ as an indicator for ozone sensitivity based on different numerical simulations, J. Geophys. Res., 104, D3, 3605-3620, doi:10.1029/1998JD100075, 1999.

Weaver, C. P., Cooter, E., Gilliam, R., Gilliland, A., Grambsch, A., Grano, D., Hemming, B., Hunt, S. W., Nolte, C., Winner, D. A., Liang, X-Z., Zhu, J., Caughey, M., Kunkel, K., Lin, J.-T., Tao, Z., Williams, A., Wuebbles, D.J., Adams, P. J., Dawson, J. P., Amar, P. He, S., Avise, J., Chen, J., Cohen, R. C., Goldstein, A. H., Harley, R. A., Steiner, A. L., Tonse, S., Guenther, A., Lamarque, J.-F., Wiedinmyer, C., Gustafson, W. I., Leung, L. R., Hogrefe, C., Huang, H.-C., Jacob, D. J., Mickley, L. J., Wu, S., Kinney, P. L., Lamb, B., Larkin, N. K., McKenzie, D., Liao, KJ., Manomaiphiboon, K., Russel, A. G., Tagaris, E., Lynn, B. H., Mass, C., Salathe, E., O’Neill, S. M., Pandis, S. N., Racherla, P. N. Rosenzweig, C., and Woo, J-H.: A preliminary synthesis of modelled climate change impacts on US regional ozone concentrations, B. Am. Meteorol. Soc., 90, 12, 1843-1863, 2009.

Wesely, M. L.: Parameterization of surface resistance to gaseous dry deposition in regional-scale numerical models, Atmos. Environ., 23, 1293-1304, 1989.

WHO: The health impacts of 2003 summer heat-waves. Briefing note for the Delegations of the fifty-third session of the WHO (World Health Organization) Regional Committee for Europe, 12 pp., 2003.

Wu, Q. Z., Wang, Z. F., Gbaguidi, A., Gao, C., Li, L. N., and Wang, W.: A numerical study of contributions to air pollution in Beijing during CAREBeijing-2006, Atmos. Chem. Phys., 11, 59976011, doi:10.5194/acp-11-5997-2011, 2011.

Yang, Q., Gustafson Jr., W. I., Fast, J. D., Wang, H., Easter, R. C., Morrison, H., Lee, Y.-N., Chapman, E. G., Spak, S. N., and Mena-Carrasco, M. A.: Assessing regional scale predictions of aerosols, marine stratocumulus, and their interactions during VOCALS-REx using WRF-Chem, Atmos. Chem. Phys., 11, 11951-11975, doi:10.5194/acp-11-11951-2011, 2011.

Zanis, P., Katragkou, E., Tegoulias, I., Poupkou, A., Melas, D., Huszar, P., and Giorgi, F.: Evaluation of near surface ozone in air quality simulations forced by a regional climate model over Europe for the period 1991-2000, Atmos. Environ., 45, 64896500, doi:10.1016/j.atmosenv.2011.09.001, 2011.

Zaveri, R. and Peters, L. K.: A new lumped structure photochemical mechanism for large-scale applications, J. Geophys. Res., 104, 30387-30415, 1999.

Zaveri, R. A., Berkowitz, C. M., Kleinman, L. I., Springston, S. R., Doskey, P. V., Lonneman, W. A., and Spicer, C. W.: Ozone production efficiency and $\mathrm{NO}_{\mathrm{x}}$ depletion in an urban plume: Interpretation of field observations and implications for evaluating O3-NO${ }_{\mathrm{x}}$-VOC sensitivity, J. Geophys. Res., 108, 4436, 
doi:10.1029/2002JD003144, 2003.

Zaveri, R. A., Berkowitz, C. M., Brechtel, F. J., Gilles, M. K., Hubbe, J. M., Jayne, J. T., Kleinman, L. I., Laskin, A., Madronich, S., Onasch, T. B., Pekour, M. S., Springston, S. R., Thornton, J. A., Tivanski, A. V., and Worsnop, D. R: Nighttime chemical evolution of aerosol and trace gases in a power plant plume: implications for secondary organic nitrate and organosulfate aerosol formation, $\mathrm{NO}_{3}$ radical chemistry, and $\mathrm{N}_{2} \mathrm{O}_{5}$ heterogeneous hydrolysis, J. Geophys. Res., 115, D12304, doi:10.1029/2009JD013250, 2010a.

Zaveri, R. A., Voss, P. B., Berkowitz, C. M., Fortner, E., Zheng, J., Zhang, R., Valente, R. J., Tanner, R. L., Holcomb, D., Hartley, T. P., and Baran, L: Overnight atmospheric transport and chemical processing of photochemically aged Houston urban and petrochemical industrial plume, J. Geophys. Res., 115, D23303, doi:10.1029/2009JD013495, 2010b.
Zhang, Y.: Online-coupled meteorology and chemistry models: history, current status, and outlook, Atmos. Chem. Phys., 8, 2895 2932, doi:10.5194/acp-8-2895-2008, 2008.

Zhang, Y., Hu, X.-M., Leung, L. R., and Gustafson Jr., W. I.: Impact of regional climate changes on biogenic emissions and air quality, J. Geophys. Res., 113, D18310, doi:10.1029/2008JD009965, 2008.

Zhang, Y., Wen, X.-Y., and Jang, C. J.: Simulating climatechemistry-aerosol-cloud-radiation feedbacks in Continental US using online-coupled WRF/Chem, Atmos. Environ., 44, 35683582, 2010. 